NBER WORKING PAPER SERIES

\title{
DON'T TAKE THEIR WORD FOR IT: THE MISCLASSIFICATION OF BOND MUTUAL FUNDS
}

\author{
Huaizhi Chen \\ Lauren Cohen \\ Umit Gurun \\ Working Paper 26423 \\ http://www.nber.org/papers/w26423 \\ NATIONAL BUREAU OF ECONOMIC RESEARCH \\ 1050 Massachusetts Avenue \\ Cambridge, MA 02138
}

November 2019, Revised August 2020

We would like to thank Robert Battalio, Nick Bollen, Robert Burn, Geoffrey Booth, John Campbell, Bruce Carlin, Tom Chang, Christine Cuny, Alex Dontoh, Mark Egan, Ilan Guttman, Yael Hochberg, Samuel Hartzmark, Alan Isenberg, Robert Jackson, Christian Julliard, Oguzhan Karakas, Craig Lewis, Dong Lou, Tim Loughran, Chris Malloy, Bill McDonald, Rabih Moussawi, Bugra Ozel, Jeff Pontiff, Joshua Ronen, Nick Roussanov, Stephen Ryan, David Solomon, Tarik Umar, Ingrid Werner, Bob Whaley, Paul Wildermuth, Paul Zarowin and seminar participants at Drexel University, the London School of Economics, New York University, the University of Notre Dame, Rice University, Vanderbilt University, the 2020 Conference on the Experimental and Behavioral Aspects of Financial Markets, the 2020 Consortium for Asset Management Conference, and the 2020 Review of Asset Pricing Studies Winter Conference for helpful comments and suggestions. We also thank James $\mathrm{Ng}$ for providing valuable research assistance. We are grateful for funding from the National Science Foundation, SciSIP 1535813. The views expressed herein are those of the authors and do not necessarily reflect the views of the National Bureau of Economic Research.

NBER working papers are circulated for discussion and comment purposes. They have not been peer-reviewed or been subject to the review by the NBER Board of Directors that accompanies official NBER publications.

(C) 2019 by Huaizhi Chen, Lauren Cohen, and Umit Gurun. All rights reserved. Short sections of text, not to exceed two paragraphs, may be quoted without explicit permission provided that full credit, including $\odot$ notice, is given to the source. 
Don't Take Their Word For It: The Misclassification of Bond Mutual Funds

Huaizhi Chen, Lauren Cohen, and Umit Gurun

NBER Working Paper No. 26423

November 2019, Revised August 2020

JEL No. G11,G12,G23,G24,G4,K0

\begin{abstract}
$\underline{\text { ABSTRACT }}$ funds report more investment grade assets than are actually held in their portfolios to important pervasive misclassification across the universe of US fixed income mutual funds. The problem is widespread - resulting in up to $31.4 \%$ of funds being misclassified with safer profiles, when funds in their peer groups. Within category groups, "Misclassified funds" moreover receive higher Morningstar Ratings (significantly more Morningstar Stars) and higher investor flows due on their actual risk, these funds are mediocre performers. These Misclassified funds also significantly underperform precisely when junk-bonds crash in returns. Misreporting is stronger following several quarters of large negative returns.

Huaizhi Chen

University of Notre Dame

238 Mendoza College of Business

hchen11@nd.edu

Lauren Cohen

Harvard Business School

Baker Library 273

Soldiers Field

Boston, MA 02163

and NBER

lcohen@hbs.edu

Umit Gurun

University of Texas at Dallas

School of Management

800 W Campbell Rd. SM41

75080 Richardson, TX

umit.gurun@utdallas.edu
\end{abstract}

We provide evidence that bond fund managers misclassify their holdings, and that these misclassifications have a real and significant impact on investor capital flows. In particular, many information intermediaries, making these funds appear significantly less risky. This results in compared against their true, publicly reported holdings. "Misclassified funds" - i.e., those that hold risky bonds, but claim to hold safer bonds -appear to on-average outperform the low-risk to this perceived on-average outperformance. However, when we correctly classify them based 


\section{Introduction}

Information acquisition is costly. However, the exact cost of collecting any piece of information depends on timing, location, a person's private information set, etc. This is in addition to the idiosyncratic characteristics and complexities of the information signal and of the asset itself. External agents - both public and private - have emerged to fill this role and reduce the cost of information acquisition. However, the value of these agents depends on how much additional information provision is needed. To this end, delegated portfolio management is the predominant way in which investors are being exposed to both equity and fixed income assets. With over 16 trillion dollars invested, the US mutual fund market, for instance, is made up of over 5,000 delegated funds and growing. While the SEC has mandated disclosure of many aspects of mutual fund pricing and attributes, different asset classes are better (and worse) served by this current disclosure level. Investors have thus turned to private information intermediaries to help fill these gaps.

In this paper, we show that for one of the largest markets in the world, US fixed income debt securities, this has led to large information gaps that have been filled by strategic-response information provision by funds. In particular, we show that the reliance on (and by) the information intermediary has resulted in systematic misreporting by funds. This misreporting has been persistent, widespread, and appears strategic - casting misreporting funds in a significantly more positive position than is actually the case. Moreover, the misreporting has a real impact on investor behavior and mutual fund success.

Specifically, we focus on the fixed income mutual fund market. The entirety of the fixed income market is similarly sized to equites (e.g., 40 trillion dollars compared with 
30 trillion dollars in equity assets worldwide). However, bonds are both fundamentally different as an asset cash-flow claim, along with having different attributes in delegated portfolios. While equity funds hold predominantly the same security type (e.g., the common stock of IBM, Apple, Tesla, etc.), each of a fixed income funds' issues differ in yield, duration, covenants, etc. - even across issues of the same underlying firm - making them more bespoke and unique. Moreover, the average active equity fund holds roughly 100 positions, while the average active fixed income fund holds over 600 issues. For example, in Figure 1, we include an excerpt from the AZL Enhanced Bond Index Fund's N-Q Schedule of Investments from September 30, 2018. ${ }^{1}$ The fund held over 700 issues, including 7 different bonds of McDonald's Corp - each with differing yields, durations, and callable features. Thus, while the SEC mandates equivalent disclosure of portfolio constituents for equity and bond mutual funds, this data is more complex in both processing and aggregating to fund-level measures for fixed income.

This has led information intermediaries to bridge this gap, providing a level of aggregation and summary on the general riskiness, duration, etc. of fixed income funds upon which investors rely. We focus on the largest of such intermediaries that provides data on categorization and riskiness at the fund level - Morningstar, Inc. In particular, we compare fund profiles provided by the intermediary (Morningstar) to investors against the funds' actual portfolio holdings. We find significant misclassification across the universe of all bond funds. This results in up to $31.4 \%$ of all funds in recent years, and is pervasive across the funds being reported as overly safe by Morningstar.

1 The full filing, including all eleven pages of holdings, is available here:
https:www.sec.gov/Archives/edgar/data/1091439/000119312518338086/d615188dnq.htm. 
How do these misclassifications occur? Morningstar "rates" each fixed income mutual fund into style boxes based their assessment of credit quality and interest rate sensitivity. For instance, a bond portfolio could be designated as a high credit quality fund with limited interest rate sensitivity. In addition, Morningstar places each fund into a category such as "Multisector Bond," or "Intermediate Core Bond." Within each of these fund categories, through a fund's realized returns and volatility Morningstar then ranks and gives an aggregate rating in the form of "Morningstar Stars." ${ }^{2}$

These Morningstar Star summaries of mutual funds have been shown throughout the literature to have a strong and significant impact on investor flow from both retail and institutional investors (Nanda, Wang, and Zheng (2004), Del Guercio and Tkac (2008), Evans and Sun (2018), Reuter and Zitzewitz (2015), Ben-David et al. (2019)). ${ }^{3}$ In addition, the data releases provided by Morningstar are used ubiquitously throughout the industry.

The central problem that we show empirically, however, is that Morningstar itself has become overly reliant on summary metrics, leading to significant misclassification across the fund universe. In particular, Morningstar requires data provision from each fund it rates (and categorizes) on the breakdown of the bonds the fund holds by risk rating classification. Specifically, what percentage of the fund's current holdings are in

\footnotetext{
${ }^{2}$ The ratings methodology and proprietary adjustments and assumptions (e.g., tax burden) are described here:

https://www.morningstar.com/content/dam/marketing/shared/research/methodology/771945_Morningst ar_Rating_for_Funds_Methodology.pdf, but to a first-order approximation, the rating is determined by their risk and net return categorization (with high expenses detracting from net returns), within official Morningstar Category (included in Appendix D).

${ }^{3}$ Investors also respond to other attention grabbing and easy to process external ranking signals, such as Wall Street Journal (Kaniel and Parham, 2017) and sustainability rankings (Hartzmark and Sussman, 2018).
} 
AAA bonds, AA bonds, BBB bonds, etc. One might think that Morningstar uses these self-reported "Summary Report," data sent to it by funds to augment the detailed holdings it acquires from the SEC filings on the fund's holdings. However, Morningstar makes credit risk-summaries solely based on this self-reported data.

Now this would be no issue if funds were accurately passing on a realistic view of the fund's actual holdings to Morningstar. Unfortunately, we show that this is not the case. We provide robust and systematic evidence that funds on average report significantly safer portfolios than they actually (verifiably) hold. In particular, funds report holding significantly higher percentages of AAA bonds, AA bonds, and all investment grade issues than they actually do. For some funds, this discrepancy is egregious - demonstrably with large holdings of non-investment grade bonds, despite being rated AAA portfolios. Due to this misreporting, funds are then misclassified by Morningstar into safer categories than they otherwise should be.

We define "Misclassified Funds" in a straightforward way: namely as those funds that are classified into a different category than they should be if their actual holdings were used as opposed to the self-reported Summary Report percentages that are used to classify them. We show that misclassification is widespread, and continues through present-day, rising up to $31.4 \%$ of high and medium credit quality funds in 2018 . Moreover, as mentioned above misclassifications are overwhelmingly one-sided: very few misstatements push funds toward a higher risk category - while the vast majority of misstatements push to a "safer" risk category.

So, what are the characteristics of these "Misclassified Funds?" First, Misclassified Funds have higher average risk - and accompanying yields on their holdings - than its category peers. This is not completely surprising, as again Misclassified Funds are holding 
riskier bonds than the correctly classified peers in their risk category. Importantly, this translates into significantly higher returns earned on-average by these Misclassified Funds relative to peer funds. They earn 3.04 basis points $(t=3.47)$ per month more, implying a $16 \%$ higher return than peers.

In order to estimate what portion of this seeming return outperformance of Misclassified Funds comes from skill versus what comes from the unfair comparison to safer funds, we turn to the funds' actual holdings reported in their quarterly filings to the SEC. We use these actual holdings to calculate the correct risk category that the fund should be classified into were it to have truthfully reported the percentage of holdings in each risk category. When we re-run the same performance regression specification, but using proper peer-comparisons, we find that Misclassified Funds no longer exhibit any outperformance. In point estimate they even underperform by 0.558 basis points per month $(t=0.65)$. Thus, it appears that $100 \%$ of the apparent outperformance of Misclassified Funds is coming from being misclassified to a less risky comparison group of funds than they should be.

However, the Misclassified Funds still reap significant real benefits from this incorrectly ascribed outperformance. Even after controlling for Morningstar category and risk classification, Morningstar rewards these Misclassified Funds with significantly more Morningstar Stars. In particular, these Misclassified Funds receive an additional 0.38 stars $(t=5.97)$, or a $12.3 \%$ increase in the number of stars. Armed with higher returns relative to (incorrect) peers and higher Morningstar Ratings, Misclassified Funds then are able to charge significantly higher expenses. In particular, they charge expense ratios that are 11.4 basis points higher than peers $(t=6.36)$. 
So what are the drivers of misclassifications? Morningstar has posited that it is due nearly entirely to their classification formula's dealing with non-rated bonds. ${ }^{4}$ We show in the Appendix, however, that even kicking out all funds that have any non-rated bonds, all of the results remain large and significant (in fact larger in point-estimate in some cases). Looking more closely at the characteristics and behaviors of the non-rated bonds themselves, and the Misclassified Funds that hold them, we find: i.) that the yields of non-rated bonds look incredibly similar to junk bond yields (and very little like the higher rated bonds that they are proposed to be by fund managers, and at which Morningstar takes their word); and ii.) that the Misclassified funds that hold these nonrated bonds curiously underperform precisely when the junk bond market crashes, along with experiencing their greatest fund outperformance when the junk bond market surges (even though they are supposedly holding predominantly highly rated, safe securities).

Importantly, we then estimate to what extent misclassification impacts investor behavior. Namely, we examine whether Misclassified Funds - even with higher fees might attract more investor flows, presumably due to the favorable comparison benefits of being misclassified. We find this to be strongly true in the data - Misclassified Funds have an increased probability of positive flows of $12 \%(t=4.95)$. The reason is two-fold. First, Misclassified Funds get a boost in realized returns (on average) given the more aggressive positions taken in their portfolios. Second, importantly they get this risk for "free" in the sense that investors believe them to be low-risk, given Morningstar's incorrect Risk Classification of the funds (we show that investors do empirically invest significantly

\footnotetext{
${ }^{4}$ In Section IV, we detail our ongoing conversations regarding these large Misclassifications. We have been in contact with Morningstar since we first began the project. Included are their proposed causes of the discrepancies, along with our replies, and evidence on their proposed causes.
} 
less in funds that they perceive to be riskier, conditional on the same Morningstar Star Rating).

Lastly, we explore the characteristics of Misclassifying Funds. In particular, we find that younger managers who are earlier in their careers tend to misclassify more often. Moreover, the more separate share classes a fund services, along with funds that are the only taxable income fund in their family are more likely to be misclassifiers. Lastly, in predicting when a fund will begin misclassifying, it appears to be when these younger fund managers of funds with numerous share classes realize a string of especially negative recent returns. In terms of the investor type that appears to respond to misclassification, we find a significant and widespread flow-response across individual and institutional investors. While in point estimate retail investors (and in particular retirement investors) appear even more swayed by misclassification, institutional investors alike invest significantly more in these funds misclassified as overly safe given their actual holdings.

The behaviors and results we document fit within a number of literature streams. First, the findings on the association between misclassification and performance are related to studies on deviations from stated investment policies by equity funds. For example, Wermers (2012), Budiono and Martens (2009) and Swinkels and Tjong-A-Tjoe (2007) show that equity mutual funds that drift from the stated investment objective do better than counterparts. Brown, Harlow and Zhang (2009) and Chan, Chen, and Lakonishok (2002) show that funds that exhibit discipline in following a consistent investment mandate outperform less consistent funds. More recently, Bams, Otten, and Ramezanifer (2017) study performance and characteristics of funds that deviate from stated objectives in the prospectuses. In the equity space, Sensoy (2009) shows that a 
fraction of size and value/growth benchmark indices disclosed in the prospectuses of U.S. equity mutual funds do not match the fund s actual style.

Second, our paper is related to the growing literature on reaching for yield of investors. Stein (2013) and Rajan (2013) note that an extended period of low interest rates can create incentives for investors to undertake greater duration risk and this could potentially create incentives for "fixed income investors with minimum nominal return needs then migrate to riskier instruments." Along these lines, Becker and Ivashina (2015) study the holdings of insurance companies and show that these firms prefer to hold higher rated bonds because of higher capital requirement constraints, but, conditional on credit ratings, their portfolios are systematically biased toward higher yield bonds. Similarly, Choi and Kronlund (2017) show the U.S. corporate bond mutual funds that tilt portfolios toward bonds with yields higher and are able to attract fund flows, especially during periods of low-interest rates. ${ }^{5}$

Moreover, our evidence is related to studies on the implications of accuracy and completeness of data sources. Along these lines, Ljungqvist, Malloy, and Marston (2009) show that I/B/E/S analyst stock recommendations have various changes across vintages and these changes (alterations of recommendations, additions and deletions of records, and removal of analyst names) are non-random and likely to affect profitability of trading signals, e.g. profitability of consensus recommendation, among others. Other examples

\footnotetext{
${ }^{5}$ Another group of papers in this literature investigates whether financial intermediaries' institutional frictions matter when they respond to the interest rates. See Drechsler, Savov, and Schnabl (2018) and Acharya and Naqvi (2019) which present models to study the conditions under which banks reach for yield by taking deposits from risk averse investors. Similar mechanisms are investigated for life insurance companies (Ozdagli and Wang (2019), pension funds holdings (Andanov, Bauer, and Cremers (2017)), and households (Lian, Ma, and Wang (2019)).
} 
include Rosenberg and Houglet (1974), Bennin (1980), Shumway (1997), Canina et al. (1998), Shumway and Warther (1999), and Elton, Gruber, and Blake (2001). The asset management literature also documents biases in reporting. In the hedge fund setting, Bollen and Poole $(2009,2012)$ exploit a discontinuity at $0 \%$ for reported returns by fund managers (i.e., investors view $0 \%$ as a natural benchmark for evaluating hedge fund performance) and document a discontinuous jump in capital flows to hedge funds around this zero-return cut-off. There is also recent work that shows the mutual funds also exhibit considerable variation in their month-end valuations of identical corporate bonds (Cici, Gibson and Merrick, 2011). Similar biases have been shown for valuation of private companies by mutual funds (Agarwal, et al. 2019). Likewise, Choi, Kronland and Oh (2018) show that zero returns are prevalent in fixed income funds and that zero-return reporting is essentially driven high illiquidity of fund holdings.

Lastly, our study contributes to the literatures on style investment. Barberis and Shleifer (2003) argue that investors tend to group assets into a small number of categories, causing correlated capital flows and correlated asset price movements. Vijh (1994) and Barberis, Shleifer, and Wurgler (2005) provide examples using S\&P 500 Index membership changes. Other examples in the empirical literature include Froot and Dabora (1999), Cooper, Gulen, and Rau (2005), Boyer (2011), and Kruger, Landier, and Thesmar (2012), who find that mutual fund styles, industries, and countries all appear to be categories that have a substantial impact on investor behavior (and asset price movements). Our work complements these studies by showing that investors categorize bond funds along the credit risk dimension as provided by the mutual fund industry's primary data source, Morningstar. 
The remainder of the paper proceeds as follows. Section II describes the data, and methodology that Morningstar uses to classify funds into categories. Section III then presents our main results on the misreporting of funds, and misclassification of these funds by Morningstar based on these faulty reports. Section III also documents the return implications, along with the real benefits for funds in terms of expenses, Morningstar Stars, investor flows, and exploring in more depth the characteristics of Misclassified Funds. Section IV then explores non-rated securities, and more of the details of the holdings and behavior of Misclassified Funds, along with discussing Morningstar's response and proposed causes. Section V concludes.

\section{Data}

In this section, we describe in detail the three major databases used in this paper. Specifically, we combine (1) the Morningstar Direct database of mutual funds and their characteristics, (2) the Morningstar database of Open-Ended Mutual Fund Holdings, and (3) our assembled collection of credit rating histories to document the substantial gap between the reported and the true portfolio compositions in fixed income funds.

\section{II.1 The Morningstar Direct Database}

Morningstar Direct contains our collection of fixed income mutual funds. These are the U.S. domiciled, dollar denominated, mutual funds that belong to the "U.S. Fixed Income" global category. We filter out the U.S. government, agency, and municipal bond funds using lagged Morningstar sub-categories. The full collection is 2,029 unique fixed income mutual funds from Q1 2003 to Q2 2018. After applying filters to maintain that 1) more than $85 \%$ of each portfolio's total holdings are observable; 2) the long side of each 
portfolio is no greater than $115 \%$ of its total value; 3 ) the TNA of each fund is over $\$ 10$ million dollars in value and 4) each fund has no more than $35 \%$ in holdings on which we have no ratings information, we have 675 unique funds. Information on these funds also come from Morningstar Direct. This data service contains detailed characteristics that originate both from the regulatory open-ended mutual fund filings and from direct fund surveys.

A key element of our study is the self-reported asset compositions from mutual fund companies. Figure 2 displays the survey used by Morningstar to collect this information from managers. The date of the survey ("Survey As Of Date") is clearly communicated to the funds to be a month-end, which we then check against the monthends corresponding to the exact quarter-end dates of holding period reporting dates to the SEC. Since the first quarter of 2017, Morningstar began calculating percent asset compositions directly from holdings, but as of March 2020, still use the self-reported, surveyed compositions to place fixed income funds in Risk Classification Styles. Notably, we also obtain historical returns, share-level investor flow, and fixed income fund styles from this dataset. For a full list of variables used in this study, refer to Appendix A.

\section{II.2. Open-Ended Mutual Fund Holdings}

Our open-ended mutual fund holdings come directly from Morningstar. This service provides us with linkages of portfolio holdings to the Morningstar Direct funds. The fixed income portfolio positions are identified by FundID, Security Name, CUSIP, and Portfolio Date. Along with the identity of these positions, we use portfolio weight, long/short profile, and asset type from this data. We focus on positions that are listed as "Bond" broad-types, and we exclude assets that are listed as swaps, futures, or options.

\section{II.3. Credit Rating Histories}


Our analysis centers on the presentation of credit risk in reports heavily used by investors, therefore we collect credit rating histories from a large variety of data sources in order to achieve comprehensive coverage. Due to Dodd-Frank, credit rating agencies are required to post their rating histories within a year of each ratings announcement as XBRL releases. These releases enable us to achieve coverage by Standard \& Poor's, Moody's, and Fitch of all CUSIP-linked securities after June 2012. In addition to these three main NRSROs, we also have coverage of Ambest, DBRS, Egan-Jones, Kroll, and Morningstar credit rating services covering all of the designated US domicile NRSROs during our sample period. We obtain credit ratings for pre-June 2012 from the Capital IQ and the Mergent FISD databases. Capital IQ contains credit rating histories from Standard \& Poor's for all of our sample history. In addition, Mergent FISD provides coverage of credit ratings from Moody's, Standard \& Poor's, and Fitch on corporates,

supranational, agency, and treasury bonds. Table 1 Panel A lists these data sources, the rating agencies reported in these sources, and the time span of their respective coverage. Panel B and Panel C tabulates the actual (as calculated using our credit rating histories) and the reported percentage holding compositions of fixed income mutual funds in the various credit rating categories from Q1 2003 to the end of each respective samples.

\section{Main Results}

\section{III.1. Diagnostics Analysis}

We start our analysis by examining histograms of fund reported percentage of holdings minus the calculated percentage holdings in various bond credit rating categories 
between Q1 2017 and Q2 2018 (Figure 3). The start of this diagnostic sample is dictated by the time that Morningstar began calculating the percent holdings of assets in each credit risk category per each fixed income fund. Ideally, if Morningstar and the bond funds in its database kept the same reporting standards in credit ratings, the fund reported percent should be almost same as the calculated percent holdings. Therefore, these histograms should report a sharp spike around zero (e.g., no discrepancies), and exhibit no significant variation. This simple diagnostic shows that, on the contrary, there is a wide dispersion of discrepancies between the records of asset compositions. Most notably, for assets above investment grade (above BBB), the percentage of assets reported by funds is markedly higher than the percentage of assets calculated by Morningstar. When we check the same gap for below investment grade and especially in unrated assets, we see an opposite pattern; i.e., the percentage of assets reported by funds is significantly lower than the percentage of assets calculated by Morningstar.

\section{III.2. Implications of Composition Disagreement - Misclassification}

In this subsection, we examine at the major implication of the difference between reported and actual holding implied composition of fund portfolios: namely misclassification of these funds. Figure 4 plots this main result graphically. More specifically, we plot the credit risk distribution of fund-quarter observations between first quarter of 2017 and the end of the second quarter of 2018. The dashed lines represent breaks in the fixed income fund style-box. AAA and AA credit quality funds are high credit quality; A and BBB credit quality funds are medium credit quality; and BB and B are low credit quality as deemed by Morningstar. 
The first (blue) bar depicts the distribution of the Morningstar Assigned Credit Risk Category of the fixed income fund. In other words, the blue bar is what mutual fund investors observe if they use Morningstar as a data provider. The second (orange) bar then depicts the same category distribution, however calculated using the fund's selfreported percentage of holdings in the various credit risk categories (from Figure 2). Specifically, using Morningstar's published methodology, this credit risk categorization is calculated as a function of a nonlinear score assigned to each category by Morningstar (see Appendix B) multiplied by the fund's self-reported percentage of holdings in AAA assets, AA assets, etc. Finally, the third (gray) bar is calculated using the fund's actual holdings and their ratings (multiplied by the same scores assigned to each rating type as in the orange bar).

If Morningstar relied on the actual holdings compositions of the funds themselves, the blue bar should track with the gray bar. If, instead, it simply "takes the funds' word for it," - simply multiplying the appropriate risk score times the self-reported percentages by the funds - the blue bar would track more closely the orange bar. From Figure 4, the blue bar tracks almost exactly the orange bar. As a result of this, many fixed income mutual funds that would have fallen into a higher credit risk bucket, are classified into safer categories.

More closely comparing these three distributions indicates that using fund selfreported credit risk composition has widely skewed the fund-level credit categorization in favor of lower perceived credit risk. For example, almost half of funds that are marked as A should not be in this category if the fund-level credit rating was assigned based on the actual holdings-implied, rather than self-reported, compositions. Likewise, half of the AAA rated funds should have received a riskier categorization according to the actual calculated 
holdings. Collectively, the evidence in this subsection suggests that when a fund reports high levels of investment grade assets, it will get classified as an investment grade fund regardless of its actual holdings.

\section{III.3. Misclassification in Detail}

In this section, we explain how systematic patterns of over/under reporting vary with respect to various assumptions regarding (1) how we select our sample and (2) how we match credit ratings to securities. We discuss the baseline analysis in detail and also provide a set of scenarios in Appendix $\mathrm{C}$ that numerates the degree of the misclassification ratio in each scenario.

We combine the credit rating history on each fixed income asset in every bond fund portfolio in order to calculate the actual percentage of assets held in each credit risk category. In other words, we match the bond positions of mutual fund portfolios to their respective ratings to calculate their average credit risk classification. These are positions that are listed as "Bond" broad-types in the Morningstar Holdings database. In our baseline analysis, we exclude assets that are listed as swaps, futures, or options, i.e. we don't assign these assets as a specific rated type or as unrated. When multiple credit rating agencies rate a single asset, we aggregate using the Bloomberg/Barclays method as prescribed by Morningstar's own methodology document. According to this method, if a security is rated by only one agency, then that rating used as the composite. If a security is rated by two agencies, then the more conservative rating is used. If all three rating agencies are present, then the median rating is assigned. Additionally, government backed

securities such as Agency Pass-thru's, Agency CMO's, and Agency ARMs are automatically designated as AAA-rated assets. We also search for treasuries and 
potentially missed government backed securities by searching keywords such as "FNMA", "U.S. Treasuries", "REFCORP", etc. - assigning them each AAA-rating. We then use these holdings calculated compositions to calculate the implied average credit risk. According to this method, roughly $24.1 \%$ of bond funds receive counter-factual credit risk categorizations that are riskier than their official credit risk categorizations in the post 2016 sample. In Appendix C, we list the potential assumptions one can make and its corresponding misclassified bond ratio.

In Table 2, we tabulate the time series of fund-quarter observations in each Morningstar Credit Quality Category using the longest time series we can obtain (20032018). Morningstar's fund level credit ratings are calculated by weighing the fund reported $\%$ of AUM in the different credit rating categories using static scores and then assigning credit risk ratings using cutoffs in the score. Morningstar changed its scoring weights and cutoffs for classifying funds in Q3 2010. Prior to the change, assets were weighed by assigning categorical scores that corresponded linearly to their credit ratings. AAA bonds weighed at 2 points, AA at 3, A at 4, and etc. The final portfolio designations were then determined at specific ranges of scores- portfolios scoring less than 2.5 were marked AAA, between 2.5 and 3.5 marked AA, and so on.

On and after Q3 2010 (through the present), nonlinear scores that correspond to default probabilities were assigned to each rating category. At the low risk end, AAA bonds began receiving a weight of 0 , with AA bonds weighted at 0.56 ; while at the higher risk end, BB bonds receive a weight of $17.78, \mathrm{~B}$ and unrated bonds a weighted of 49.44, and B minus bonds receive a weight of 100. The classification cutoffs then were changed to correspond to the new scores of the respective bonds classes. This effectively means that any reporting of low-credit quality bond assets would likely move a portfolio toward 
a higher risk category. In effect, the methodology change made it very difficult for portfolios to have high yield bonds while still maintaining a low credit risk classification.

In Table 2, the final column \# Misclassified is then the number of observations per year that have riskier counter-factual ratings than their official ratings. These numbers suggest that number of misclassified funds increased dramatically over the years but most notably post-August 2010 - the year Morningstar changed the way it calculated average credit risk. We reproduce the weighting scheme in accordance to Morningstar's published methodology in Appendix B. The result of this change in methodology (as seen in Appendix B and described above) was a much higher relative penalty placed on lowerrated bonds vs. higher-rated bonds. This resulted in a much more composition dependent categorization of fixed income funds (given the drastic ratings penalty-spreads). For our main regression analysis, we focus on the sample of funds that are misclassified from Q3 2010, on which Morningstar began its new bond credit risk classification system, to Q2 2018.

\section{III.4. Fund Performance and Misclassification}

A natural follow-up question is whether these misclassified funds are, in fact, different than their risk-category peers, given that they hold a larger percentage of lower credit-quality assets than their risk category peers (and lower credit-quality assets than their classifications suggest they should be). We explore both the risk and return characteristics of these misclassified funds vs. their correctly classified peers in this section.

In Table 3, we first regress the yield metrics of a fund on our metric of misclassification. Specifically, we define a Misclassified dummy variable which takes a value of one if the Morningstar credit quality (High or Medium) is higher than the 
counterfactual (true) credit quality calculated using the actual underlying holdings, and zero otherwise. We use three different types of yield metrics. In the first column, we use yields reported to Morningstar by the funds themselves. These yields are voluntarily reported. In the second column, we use the yields calculated by Morningstar. The sample size in this second column is limited because calculated holding yields were only available after 2017. In the third column, we use twelve-month yield which combines total interest, coupon, and dividend payments. We also include a credit score variable (the reported compositions score that is used to classify fund credit risks) - with increasing values signifying greater credit risk; and the duration of the bonds (as reported by the funds) as a control variable to capture the interest rate risk of the bond portfolio. In addition, we include a (Time x Morningstar Category) fixed effect to control for common variation in returns and risk due to category-time specific variation (Appendix D lists the official Morningstar Categories). In Columns 1-3, we also include a (Time x Morningstar Reported Risk Style) fixed effect to our specification which absorbs the mean yield of each funds corresponding Morningstar fund calculated risk classification in the given year. Doing so allows us to address the concern that a group of funds in a particular year systematically misclassify their riskiness and that misclassified dummy essentially captures this fund style related reporting choice. We cluster the standard errors by time and fund to address the time series cross-sectional and individual variation in risk.

From Table 3, all three yield columns point to the same empirical regularity. Namely, that there is a strong relation between misclassification and yields: Misclassified funds have significantly higher yields. The annualized reported yield to maturity is 27.7 basis points higher $(t=5.49)$, whereas the calculated yield from the holdings (second 
column) and the payout yield are 23.7 and 19.0 basis points higher, respectively, for misclassified funds over their official peers.

In Columns 4-6, we then explore how these misclassified funds would compare were we to compare them against their correctly classified risk peers. In particular, for each fund, we use its underlying holdings to calculate its Correct Fund Risk Style - note that for already correctly classified funds, this will be the same as Columns 1-3, and only will now be changed, and correctly reflect the risk of the underlying holdings, for misclassified funds.

Columns 4-6 of Table 3 then conduct the identical tests as Columns 1-3, but replace the Time x Morningstar Reported Risk Style fixed effect with Time x Correct Fund Risk Style fixed effect. From Columns 4-6, the Misclassified dummy variable drops in magnitude to near zero and is statistically insignificant. What this means is that when you properly account for the true risk of these underlying funds' holdings (based on their actual holdings, as opposed to what they self-report to Morningstar, and that Morningstar classifies risk classification based-upon), they have identical yields to their correct peer funds.

Next, we examine the performance of these misclassified funds vs. their correctly risk-classified peer funds. In Table 4, we regress actual fund returns on the Misclassified dummy, along with the same controls and fixed effects from Table 3. In the Columns 12, we include Time x Morningstar Reported Risk Style fixed effects as we do in the previous table. From these columns, misclassified funds significantly outperform their Risk Style and Morningstar Fund Category peers, controlling for other determinants of returns. In particular, Column 2 implies that these funds outperform by 3.04 basis points per month $(t=3.42)$, which represents a $16 \%$ higher return than peers. 
In Columns 3-4, we then replace this Morningstar Reported Risk Style fixed effect with Time x Correct Fund Risk Style fixed effect. The idea is to estimate the percentage of this seeming return outperformance of Misclassified Funds that comes from skill versus what percentage comes from the unfair comparison to safer funds. From Columns 3-4, once we compare Misclassified funds against their correctly classified peers, they exhibit no outperformance. In fact, in point estimate, from Column 4, once compared against their correct risk peers, Misclassified funds actually slightly underperform in point estimate by 0.558 basis points per month $(t=0.65)$, though insignificantly so. The sum of the results in Table 4 suggests that Misclassified funds appear to outperform, but that $100 \%$ of that outperformance comes from being compared against an incorrect (overly safe) set of category peers.

\section{III.5. Incentives to Misclassify}

In our next analysis, we test whether misclassified funds obtain various benefits from being classified in less-riskier groups of funds. From Table 4, Misclassified funds do appear to generate outperformance to their incorrectly classified risk peers (which disappears when comparing against the correct risk-peer funds). The first benefit we explore in this section is the awarding of Morningstar Stars by the Morningstar, Inc. itself. As referenced above, Morningstar uses their Star rating system to reward funds for "true outperformance" in their designated Morningstar Category (which are listed in Appendix D). These Morningstar Stars have been shown by a vast literature to have a strong relationship to investor fund flows (for instance, Del Guercio and Tkac (2008), Evans and Sun (2018), Reuter and Zitzewitz (2015), Ben-David et al. (2019)), and by revealed 
preference are used by many fund companies as an explicit part of their marketing strategy.

We explore this relationship by regressing various Morningstar rating metrics on the Misclassified dummy, the reported credit rating score, reported duration, average expense ratio, Time x Morningstar Reported Risk Style fixed effects, and importantly the Time x Morningstar Category fixed effect (as this is the peer group against which Morningstar asserts to make its risk and net return comparison). Because the ratings and expenses are reported at the share class level, the fund level Morningstar Ratings and the Average Expense ratio are calculated as the value weighted average of their respective share-class level values.

The results are reported in Table 5 . Table 5 shows that there are economically large increase in Morningstar Stars awarded to Misclassified funds. Misclassified funds receive $0.17(t=3.77)$ to $0.38(t=5.97)$ more Morningstar Stars compared to their peer funds. This level of higher rating corresponds to $18 \%$ to $41 \%$ of a standard deviation in Morningstar Stars ratings, or up to a $12.3 \%$ increase in the number of stars.

In Table 6, we then investigate whether misclassified funds are able to charge higher expense ratios than their peers. Perhaps intuitively, we explore whether Misclassified funds charge higher expenses to their investors because their "reported" (but not actual) performance is better and relatedly that they are able to be rewarded higher Morningstar Star ratings.

Prior research has explored in depth whether equity mutual funds are able to consistently earn positive risk-adjusted returns, and if so, whether funds are able to 
charge, in equilibrium, higher fees for this outperformance. ${ }^{6}$ The line of argument often suggests that there be a positive relation between before-fee risk-adjusted expected returns and fees. On the other hand, Gil-Bazo and Ruiz-Verdu (2009) argue funds often engage in strategic fee-setting in the presence of investors with different degrees of sensitivity to performance and this could lead to an ambiguous - or even negative - relation between fund performance and fee.

Table 6 contains the results exploring fees of Misclassified funds. From Column 3 in Table 6, we find that, on average, the misclassified funds have 7.6 basis point higher $(t$ $=4.17)$ average annual expenses than funds within the same style-category, which implies they are able to charge $10.8 \%$ higher fees than peers. ${ }^{7}$

In Table 7, we then investigate the fund flows to Misclassified funds. There are several reasons why misclassification might be related to bond fund flows. First, Barberis and Shleifer (2003) argue that investors tend to group assets into a small number of categories, causing correlated capital flows and correlated asset price movements. If an asset ends up being in the wrong classification category then it may receive a disproportionately higher (or lower) investment than its correct bucket - especially if it has a favorable ranking attribute within that category (e.g., reported returns). Several

\footnotetext{
${ }^{6}$ See, for example, Brown and Goetzmann (1995); Carhart (1997); Daniel et al. (1997); Wermers (2002); Cohen, Coval, and Pastor (2005); Kacperczyk, Sialm, and Zheng (2005); Kosowski et al. (2006).

${ }^{7}$ Past research in the equity space has investigated whether funds alter their investment style and whether funds with characteristics are more likely to deviate from stated objectives in their mandate due to various reasons including fund manager incentives. In particular, DiBartolomeo and Witkowskip (1997) show that younger mutual funds are particularly prone to misclassification and Frijns et al. (2013) show that funds which switch across fund objectives aggressively tend to have higher expense ratios. Along these lines, Huang, Sialm and Zhang (2011) argue that funds with higher expense ratios experience more severe performance consequences when they alter risk. Relatedly, Deli (2002) and Coles, Suay, and Woodbury (2000) argue that fee structures could vary across funds because of difficulty of managing a riskier portfolio. In order to test these ideas, in Appendices $\mathrm{J}$ and $\mathrm{K}$, we both explore fund age, along with separating fees into advisor and distribution fees charged by managers (where available and reported).
} 
papers in the literature show the power of style investment in explaining asset flows. Froot and Dabora (1999), Cooper, Gulen, and Rau (2005), Boyer (2011), and Kruger, Landier, and Thesmar (2012), find that mutual fund styles, industries, and countries all appear to be categories that have a substantial impact on investor behavior (and asset price movements).

We test for the relationship between Misclassification and flows in two ways. First, we simply test whether Misclassified Funds receive higher inflows; they do - significantly higher inflows. This is shown in Column 1 of Table 7. The coefficient on Misclassified of $0.0637(t=4.95)$ implies over $12 \%$ higher probability of positive flows for Misclassified funds controlling for other determinants. However, given that Misclassification is also related to other attributes which drive flows (e.g., Morningstar Stars), it is difficult to interpret what magnitude of the flows might be coming from the Misclassification itself. Thus, we additionally run a two stage least squares procedure. In the first stage, we estimate - controlling for other fund, category, and time effects - the impact of being a Misclassified fund on the number of Morningstar Stars that a fund receives (run in Table 5). We then take this estimate of just the extra portion of Morningstar Stars a Misclassified Fund gets from being misclassified, and take this piece of their Stars Misclassified Stars - to see if it has an impact on investor flows. We find that it has a significantly positive impact. In particular, Column 2 of Table 7 implies that a one Misclassified Star increase raises the probability of positive flows by almost $17.1 \%$ $(t=5.16)$.

We also examine if there is a difference between investors (e.g., institutional vs. retail) with respect to their behavioral responses to misclassified funds. From Morningstar Direct, we can classify share classes into a number of specific categories: in particular, 
into Institutions, Retirement, and Retail classes. These are shown in Columns 3-5 of Table 7. From these columns, we first see that the positive flows accruing to Misclassified funds appear to be coming broadly across all types of investors. In particular, the coefficient on Misclassified is large and highly significant across all 3 share-class categories. That said, individual investors do - in point estimate - seem to be slightly more tilted to misclassifying funds than institutions. While misclassified Institutional share classes are $11.4 \%$ more likely to receive positive investor flows than other funds of their same share class, misclassified Retail and Retirement share classes increased their probabilities by over $20 \%$ from their respective unconditional means. Even amongst individual investors, the fact that retirement investors appear to be most influenced by Misclassified funds in terms of flows, is consistent with investor sophistication findings; Fisch et al. (2019) find that financial literacy is significantly lower for retirement investors than other types of retail investors.

\section{III.6. Who Misclassifies?}

From investor behavior with respect to these Misclassified funds vs. other funds, we turn to examining the characteristics that correlate with a fund being a Misclassified fund, along with the determinants of misclassification of a fund over time. In particular, we first run a characteristics-regression with the dependent variable being whether the fund is a Misclassified fund (or not), in order to examine which characteristics are more related to being a Misclassified fund. The results of the characteristics regressions are in Table 8. From Table 8, we note a number of characteristics of misclassifiers. In particular, from the full specification in Column 3, younger and larger funds tend to misclassify, as do managers earlier in their careers (with less tenure). Moreover, the more separate share classes a fund has, the more likely it is to be a misclassifier. Additionally, if the fund is 
the only taxable fixed income fund in the family, it has a higher likelihood of being a misclassifier. Lastly, consistent with the advantages that we found in the paper from misclassifying (i.e., being able to hold higher yielding bonds than peers, resulting in higher returns and flows), we find that misclassifying funds are related to having a significantly higher share of the fund's risk category (Market Share) and higher realized returns when holding the (misclassified) riskier positions.

To explore the time-series decisions of funds to begin and end misclassifying, we define two variables to capture fund reporting behavior over time. The first variable, Start Being Misclassified, takes a value of one if a previously correctly classified fund starts misclassifying its holdings. In addition to this variable, we define another indicator variable, End Being Misclassified, which takes a value of one if a previously misclassified fund starts correctly classifying its holdings. We then test the determinants of both of these in Panel A of Table 9. It is again younger managers of funds that offer more share classes, who have experienced particularly poor recent performance. Then, in predicting when a fund will end being a misclassifier, it appears to be when these younger fund managers of funds with numerous share classes realize a string of especially positive recent returns.

In Panel B of Table 9, we then explore the geographic location of misclassifying (vs. non-misclassifying) funds. From Panel B, relative to the Northeast (which has the highest prevalence of mutual funds, and is the omitted category), funds in the Midwest appear less likely, on average, to misclassify, while funds in the South appear more likely misclassify.

Lastly, we explore the impact of a "family specific" effect on misclassification of funds. In Panel $\mathrm{C}$ of Table 9, the inclusion of a family fixed effect explains a large 
percentage of the variation in misclassification. In particular, in Column 1 we include only Year-Quarter FEs, explaining $0.3 \%$ of the variation. When we include family fixed effects in Column 2, the $\mathrm{R}^{2}$ increases to $22.7 \%$. Thus, family specific factors appear to explain over a fifth of the variation in which funds misclassify across the universe and across time (controlling for any time-specific variation that might impact all funds equivalently, such as the Fed lowering target interests or a pervasive change in ratings). Moreover, Column 3 then adds a Fund specific fixed-effect in addition, with $\mathrm{R}^{2}$ rising $49.4 \%$. This suggests that even with the importance of family effects in determining misclassifying, a sizable amount of the variation remains determined at the fund-level (as also suggested in Table $8)$.

\section{Misclassified Funds Returns across Junk Bond Regimes, Non-Rated Securities, and Morningstar's Response}

We have been in contact with Morningstar since the beginning of the project. We were first referred to technical support teams with whom we checked each step of our process and the self-reported surveys that fund managers fill out, along with Morningstar's scoring process, to ensure that we had each step correct. Then, following the first posting of a draft of our work, Morningstar released an official organizational response shown in Appendix E. In Appendix F, we include our reply to Morningstar's initial comments. Morningstar then responded with a second response contained in Appendix G, along with our reply to these comments in Appendix H.

Essentially, Morningstar posited two points in their initial response. First, that the star analysis in particular was mis-specified due to not comparing within Morningstar 
Official Fund Category (Appendix D). ${ }^{8}$ As seen in the current draft, all specifications include official Morningstar Category fixed effects. From these tests, comparing within categories, all of our results are strong and significant. Which is to say: Misclassified funds receive significantly more stars than peer-group funds within an official Morningstar Category. Second, Morningstar posited that the discrepancies are due nearly entirely to their classification formula's dealing with non-rated bonds. We show in Appendix F, however, that even kicking out all funds that have any non-rated bonds, all of the results remain large and significant (in fact larger in point-estimate in some cases).

We then look more closely at the characteristics and behaviors of the non-rated bonds themselves, and the Misclassified Funds that hold them. First, we look at the nonrated bonds themselves in Table 10. From Table 10, the yields of non-rated bonds look incredibly similar to junk bond yields, and very little like the higher rated bonds that they are proposed to be by fund managers, and at which Morningstar takes their word.

Second, in Table 11, we examine the performance of Misclassified funds around times of junk bond crashes, and junk bond outperformance. If these classified into "safer" categories by Morningstar truly did hold the safe, high credit-quality bond issues they claimed - and represented by Morningstar in their relatively safe risk classifications of the funds - the funds should not be sensitive to the movement of junk bonds. However, this is not what is seen in Table 11. Table 11 shows that Misclassified funds' over- and underperformance relative to their peer funds relates strongly to junk bond returns (captured

\footnotetext{
${ }^{8}$ In addition to the analyses in Appendix D, in Appendix I we replicate the Morningstar Star Rating methodology itself. We show that Misclassified funds receive significantly more Stars from taking on more risk in their underlying portfolios, and get these Stars for "free" in the sense investors perceive these funds as being less risky and so allocate significantly more flows to them as a result (as we show that even conditional on the same number of Stars, investors allocate significantly more flows to funds that they believe attain these flows while taking on lower risk).
} 
by the return on a junk bond index - JNK). Misclassified funds significantly underperform precisely when the junk bond market crashes, along with experiencing their greatest fund outperformance when the junk bond market surges (even though they are supposedly holding chiefly highly rated, safe securities).

Morningstar's second reply (Appendix G) then shifts focus to more technical points, stating: "To that end, we were able to largely reproduce the authors' multivariate analysis of the binary "misclassified" dummy variable they defined and various ratings metrics." In Appendix H, we explore the points and claims from this response in further detail in the data, unfortunately not finding strong support.

\section{Conclusion}

Investors rely on external information intermediaries to lower their cost of information acquisition. While prima facie this brings up no issues, if the information that the intermediary is passing on is biased, these biases propagate throughout markets and can cause real distortions in investor behavior and market outcomes. We document precisely this in the market for fixed income mutual funds. In particular, we show that investors' reliance on Morningstar has resulted in significant investment based on verifiably biased reports by fund managers that Morningstar simply passes on as truth.

We provide the first systematic study that compares fund reported asset profiles provided by Morningstar against their actual portfolio holdings, and show evidence of significant misclassification across the universe of all bond funds. A large portion of bond funds are not passing on a realistic view of the fund's actual holdings to Morningstar and Morningstar creates its risk classifications, and even fund ratings, based on this selfreported data. Up to $31.4 \%$ of all funds in recent years, are reported as overly safe by 
Morningstar. This misreporting has been not only persistent and widespread, but also appears to be strategic. We show that misclassified funds have higher average risk - and accompanying yields on their holdings - than their category peers. We also show evidence suggesting the misreporting has real impacts on investor behavior and mutual fund success. Misclassified funds reap significant real benefits from this incorrectly ascribed outperformance in terms of being able to charge higher fees and receiving higher flows from investors.

We exploit a novel setting in which investors reliance on external information intermediaries can lead to predictable patterns in fund ratings and capital flows, and in which we can ex-post verify the veracity of the information conveyed. We believe that our study is a first step to think about a market design in which information intermediaries have more aligned incentives to better process and deliver the information they gather from market constituents. Future research should explore alternate monitoring and verification mechanisms for the increasingly complex information aggregation in modern financial markets, along with ways that investors can engage as important partners in information collection and price-setting. 


\section{References}

Acharya, V. and Naqvi, H., 2019. On reaching for yield and the coexistence of bubbles and negative bubbles. Journal of Financial Intermediation, 38, pp.1-10.

Agarwal, V., Barber, B.M., Cheng, S., Hameed, A. and Yasuda, A., 2019. Private company valuations by mutual funds. Available at SSRN 3066449.

Andonov, Aleksandar, Rob M.M.J. Bauer, and K.J. Martijn Cremers, 2017. Pension Fund Asset Allocation and Liability Discount Rates, Review of Financial Studies 30, 2555-2595.

Bams, Dennis, Otten, Roger, and Ramezanifar, Ehsan, 2017. Investment style misclassification and mutual fund performance. In 28th Australasian Finance and Banking Conference.

Barberis, N., and Shleifer, A., 2003. Style investing, Journal of Financial Economics 68, 161-199.

Barberis, N., Shleifer, A., and Wurgler, J. 2005. Comovement, Journal of Financial Economics 75, 283-317.

Becker, Bo and Victoria Ivashina, 2015. Reaching for Yield in the Bond Market, Journal of Finance 70, 1863-1901.

Brown, Stephen J., and William N. Goetzmann, 1997. Mutual fund styles, Journal of Financial Economics 43, no. 3, 373-399.

Brown, Keith C., Harlow, W. Van and Zhang, Hanjiang, 2009. Staying the course: The role of investment style consistency in the performance of mutual funds. Available at SSRN 1364737.

Ben-David, Itzhak and Li, Jiacui and Rossi, Andrea and Song, Yang, 2019. What do mutual fund investors really care about?, Fisher College of Business Working Paper No. 2019-03-005.

Bennin, Robert, 1980. Error rates in CRSP and COMPUSTAT: A second look, Journal of Finance 35, 1267-1271.

Boyer, Brian H., 2011. Style-related comovement: Fundamentals or labels?, Journal of Finance 66, 307-332.

Bollen, Nicholas and Pool, Veronica, 2009. Do hedge fund managers misreport returns? Evidence from the pooled distribution, Journal of Finance, 2257-2288.

Bollen Nicholas and Pool, Veronica, 2012. Suspicious patterns in hedge fund returns and risk of fraud, Review of Financial Studies 25, 2673-2702. 
Budiono, Diana and Martens, Martens, 2009. Mutual fund style timing skills and alpha. Available at SSRN 1341740.

Canina, Linda, Roni Michaely, Richard Thaler, and Kent Womack, 1998. Caveat compounder: A warning about using the daily CRSP equal-weighted index to compute long-run excess returns, Journal of Finance 53, 403-416.

Carhart, Mark M, 1997. On persistence in mutual fund performance. The Journal of Finance 52, no. 1, 57-82.

Chan, Louis K., Chen, Hsiu-Lang, and Lakonishok, Joseph, 2002. On mutual fund investment styles. The Review of Financial Studies 15, pp.1407-1437.

Choi, Jaweon, Kronlund, Mathias and Oh, Ji Y.J., 2018. Sitting Bucks: Zero Returns in Fixed Income Funds, Working Paper.

Choi, Jaewon, and Mathias Kronlund, 2017. Reaching for Yield in Corporate Bond Mutual Funds, Review of Financial Studies 31, 1930-1965.

Cici, Gjergji, Gibson, Scott and Merrick Jr, John J., 2011. Missing the marks? Dispersion in corporate bond valuations across mutual funds. Journal of Financial Economics, 101(1), pp.206-226.

Cohen, Randolph B., Coval, Joshua D. and Pástor, Lubos, 2005. Judging fund managers by the company they keep. The Journal of Finance, 60(3), pp.1057-1096. Vancouver

Coles, J.L., Suay, J. and Woodbury, D., 2000. Fund advisor compensation in closed- end funds. The Journal of Finance, 55(3), pp.1385-1414.

Cooper, Michael, Gulen, Huseyin, Rau, Raghavendra, 2005. Changing names with style: Mutual fund name changes and their effects on fund flows, Journal of Finance 60, 28252858 .

Daniel, Kent, Mark Grinblatt, Sheridan Titman, and Russ Wermers, 1997. Measuring mutual fund performance with characteristics-based benchmarks, Journal of Finance 52, $1035-1058$.

Del Guercio, Diane, and Paula A. Tkac, 2008. Star power: The effect of Morningstar ratings on mutual fund flow, Journal of Financial and Quantitative Analysis 43, 907-936.

Deli, Daniel N., 2002. Mutual fund advisory contracts: An empirical investigation. The Journal of Finance, 57(1), pp.109-133.

Di Bartolomeo, Dan, and Erik Witkowski, 1997. Mutual fund misclassification: Evidence based on style analysis, Financial Analysts Journal 53, no. 5, 32-43.

Drechsler, Itamar, Alexi Savov, and Philipp Schnabl, 2018. .A Model of Monetary Policy and Risk Premia., Journal of Finance 73, 317-373. 
Elton, Edwin J., Martin J. Gruber, and Christopher R. Blake, 2001. A first look at the accuracy of the CRSP Mutual Fund Database and a comparison of the CRSP and Morningstar Mutual Fund Databases, Journal of Finance 56, 2415-2430.

Evans, Richard B., and Yang Sun, 2018. Models or stars: The role of asset pricing models and heuristics in investor risk adjustment, Working paper, University of Virginia.

Fisch, J.E., Lusardi, A. and Hasler, A., 2019. Defined contribution plans and the challenge of financial illiteracy. Cornell Law Review, pp.19-22.

Frijns, Bart, Aaron B. Gilbert, and Remco CJ Zwinkels, 2013. On the Style-based Feedback Trading of Mutual Fund Managers. Available at SSRN 2114094.

Froot, Kenneth, Dabora, Emil, 1999. How are stock prices affected by the location of trade? Journal of Financial Economics 53, 189-216.

Gil-Bazo, Javier and Pablo Ruiz-Verdu, 2009. The relation between price and performance in the mutual fund industry, The Journal of Finance 64, no. 5, 2153-2183.

Hartzmark, Samuel M., and Abigail Sussman, 2018. Do investors value sustainability? A natural experiment examining ranking and fund flows, Working paper, University of Chicago.

Huang, Jennifer, Clemens Sialm, and Hanjiang Zhang, 2011. Risk shifting and mutual fund performance. Review of Financial Studies 24, no. 8, 2575-2616.

Kacperczyk, Marcin, Clemens Sialm, and Lu Zheng, 2008. Unobserved actions of mutual funds, Review of Financial Studies 21, no. 6, 2379-2416.

Kaniel, Ron, and Robert Parham, 2017. WSJ category kings: The impact of media attention on consumer and mutual fund investment decisions, Journal of Financial Economics 123, 337-356.

Kruger, P., Landier, A., and Thesmar, D., 2012. Categorization bias in the stock market. Unpublished working paper. University of Geneva, Toulouse School of Economics, and HEC.

Kosowski, Robert, Timmermann, Allan, Wermers, Russ and White, Hal, 2006. Can mutual fund "stars" really pick stocks? New evidence from a bootstrap analysis. The Journal of Finance, 61(6), pp.2551-2595.

Lian, Chen, Yueran Ma, and Carmen Wang, 2019. Low Interest Rates and Risk-Taking: Evidence from Individual Investment Decisions, Review of Financial Studies 32, 21072148.

Ljungqvist, Alexander, Malloy, Christopher and Marston, F., 2009. Rewriting history. The Journal of Finance, 64(4), pp.1935-1960. 
Nanda, Vikram, Wang, Z. Jay, and Zheng Lu., 2004. Family values and star phenomenon: strategies for mutual fund families, 17(3), pp.667-698.

Ozdagli, Ali and Zixuan Wang, 2019. Interest Rates and Insurance Company Investment Behavior, unpublished paper, Federal Reserve Bank of Boston and Harvard Business School.

Rajan, Raghuram, 2013. A Step in the Dark: Unconventional Monetary Policy After the Crisis., Andrew Crockett Memorial Lecture, Bank for International Settlements. Available online at https://www.bis.org/events/agm2013/sp130623.htm.

Reuter, Jonathan, and Eric Zitzewitz, 2015. How much does size erode mutual fund performance? A regression discontinuity approach, Working paper, Boston College.

Rosenberg, Barr, and Michel Houglet, 1974. Error rates in CRSP and Compustat data bases and their implications, Journal of Finance 29, 1303-1310.

Sensoy, B.A., 2009. Performance evaluation and self-designated benchmark indexes in the mutual fund industry. Journal of Financial Economics, 92(1), pp.25-39.

Shumway, Tyler, 1997. The delisting bias in CRSP data, Journal of Finance 52, 327-340.

Shumway, Tyler, and Vincent A. Warther, 1999. The delisting bias in CRSP's NASDAQ data and its implications for interpretation of the size effect, Journal of Finance 54, 23612379 .

Stein, Jeremy, 2013, Overheating in Credit Markets: Origins, Measurement, and Policy Responses., Research Symposium, Federal Reserve Bank of St. Louis. Available online at https://www.federalreserve.gov/newsevents/speech/stein20130207a.htm.

Swinkels, Laurens, and Liam Tjong-A-Tjoe, 2007. Can mutual funds time investment styles?, Journal of Asset Management 8, no. 2, 123-132.

Vijh, Anand, 1994. S\&P 500 trading strategies and stock betas, Review of Financial Studies 7, 215-251.

Wermers, Russ, 2012. Matter of style: The causes and consequences of style drift in institutional portfolios. Available at SSRN 2024259. 


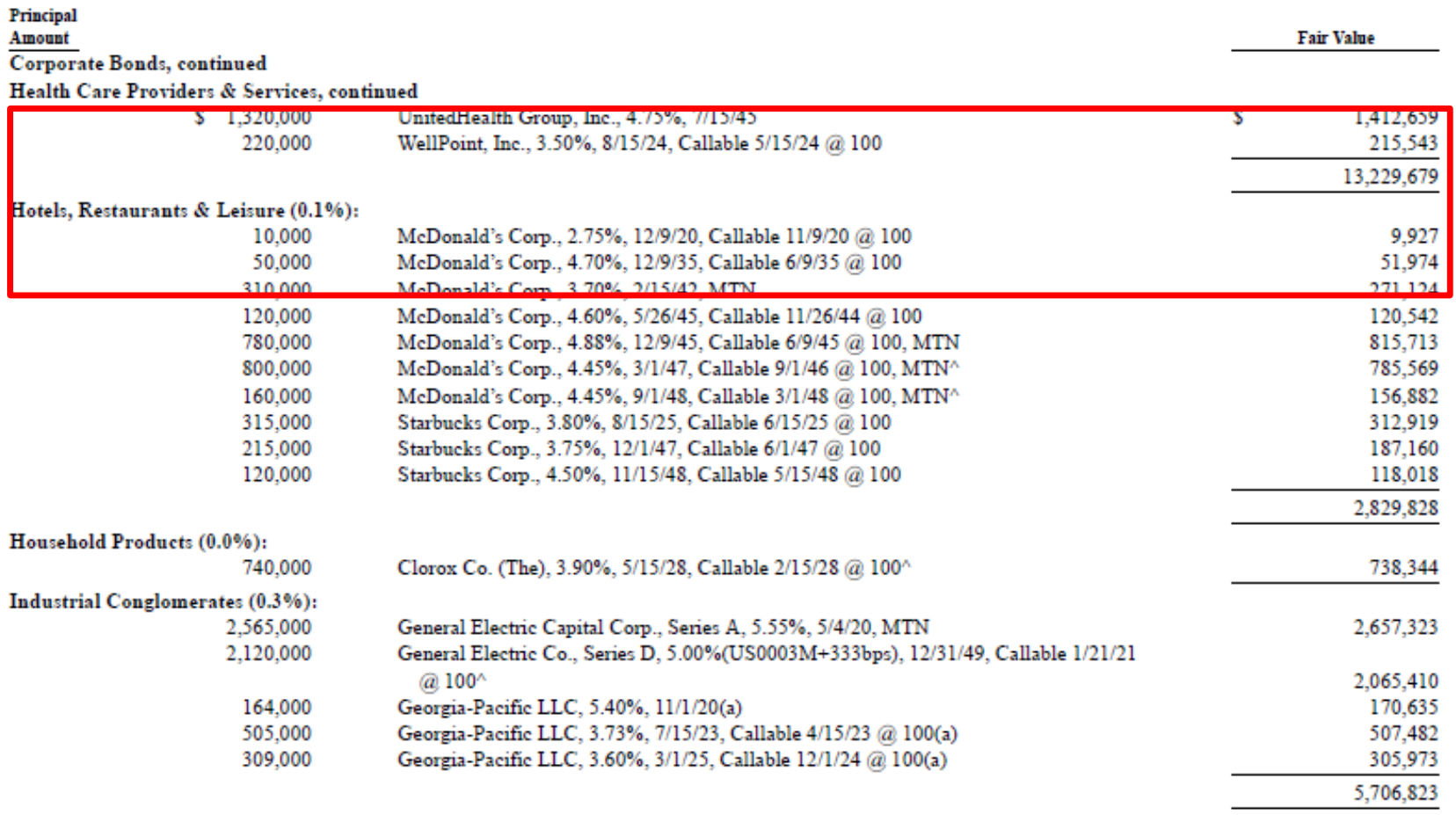

\section{Figure 1. Sample Bond Fund Holding Data}

This figure contains an excerpt from the AZL Enhanced Bond Index Fund's September 30, 2018 N-Q Schedule of Investments held (source:

https:www.sec.gov/Archives/edgar/data/1091439/000119312518338086/d615188dnq.htm 


\begin{tabular}{|c|c|c|c|c|c|c|c|c|c|c|}
\hline SURVEY AS & UNIQUE & FUND NAME & \multicolumn{8}{|c|}{ CREDIT RATINGS RISK } \\
\hline OF DATE & IDENTIFIER & & AAA & AA & A & BBB & BB & B & BELOW B & NOT RATED \\
\hline $\begin{array}{l}\text { (mm/dd/yyyy) } \\
\text { or (yyyy-mm-dd) } \\
\text { Must be a month-end } \\
\text { date. All other dates } \\
\text { will be rounded } \\
\text { (rounded forward } \\
\text { where dd }=>16 \text { ). Do } \\
\text { not include formulas. }\end{array}$ & $\begin{array}{c}\text { Char(75) } \\
\text { This MUST be the } \\
\text { same identifier used } \\
\text { for submitting portfolio } \\
\text { holdings. Please } \\
\text { contact us if you do } \\
\text { not have this } \\
\text { information. }\end{array}$ & $\begin{array}{c}\text { Char(75) } \\
\text { Must be kept } \\
\text { consistent per fund, } \\
\text { per fund file. Can } \\
\text { vary from delivery to } \\
\text { delivery due to name } \\
\text { changes. }\end{array}$ & $\begin{array}{l}\text { Numeric(5.2) } \\
\% \text { of assets for } \\
\text { this rating } \\
\text { assigned by a } \\
\text { Nationally } \\
\text { Recognized } \\
\text { Statistical Rating } \\
\text { Organizations. }\end{array}$ & $\begin{array}{c}\text { Numeric(5.2) } \\
\% \text { of assets for } \\
\text { this rating } \\
\text { assigned by a } \\
\text { Nationally } \\
\text { Recognized } \\
\text { Statistical Rating } \\
\text { Organizations. }\end{array}$ & \begin{tabular}{|} 
Numeric(5.2) \\
$\%$ of assets for \\
this rating \\
assigned by a \\
Nationally \\
Recognized \\
Statistical Rating \\
Organizations.
\end{tabular} & $\begin{array}{l}\text { Numeric(5.2) } \\
\% \text { of assets for } \\
\text { this rating } \\
\text { assigned by a } \\
\text { Nationally } \\
\text { Recognized } \\
\text { Statistical Rating } \\
\text { Organizations. }\end{array}$ & $\begin{array}{c}\text { Numeric(5.2) } \\
\% \text { of assets for } \\
\text { this rating } \\
\text { assigned by a } \\
\text { Nationally } \\
\text { Recognized } \\
\text { Statistical Rating } \\
\text { Organizations. }\end{array}$ & $\begin{array}{c}\text { Numeric(5.2) } \\
\% \text { of assets for } \\
\text { this rating } \\
\text { assigned by a } \\
\text { Nationally } \\
\text { Recognized } \\
\text { Statistical Rating } \\
\text { Organizations. }\end{array}$ & \begin{tabular}{|c|} 
Numeric(5.2) \\
$\%$ of assets for \\
this rating \\
assigned by a \\
Nationally \\
Recognized \\
Statistical Rating \\
Organizations.
\end{tabular} & $\begin{array}{c}\text { Numeric(5.2) } \\
\% \text { of assets that } \\
\text { do not have a } \\
\text { rating. }\end{array}$ \\
\hline
\end{tabular}

Figure 2. Morningstar Survey

This figure contains a portion of the fixed income template sent by Morningstar to survey mutual funds in August 2019. 

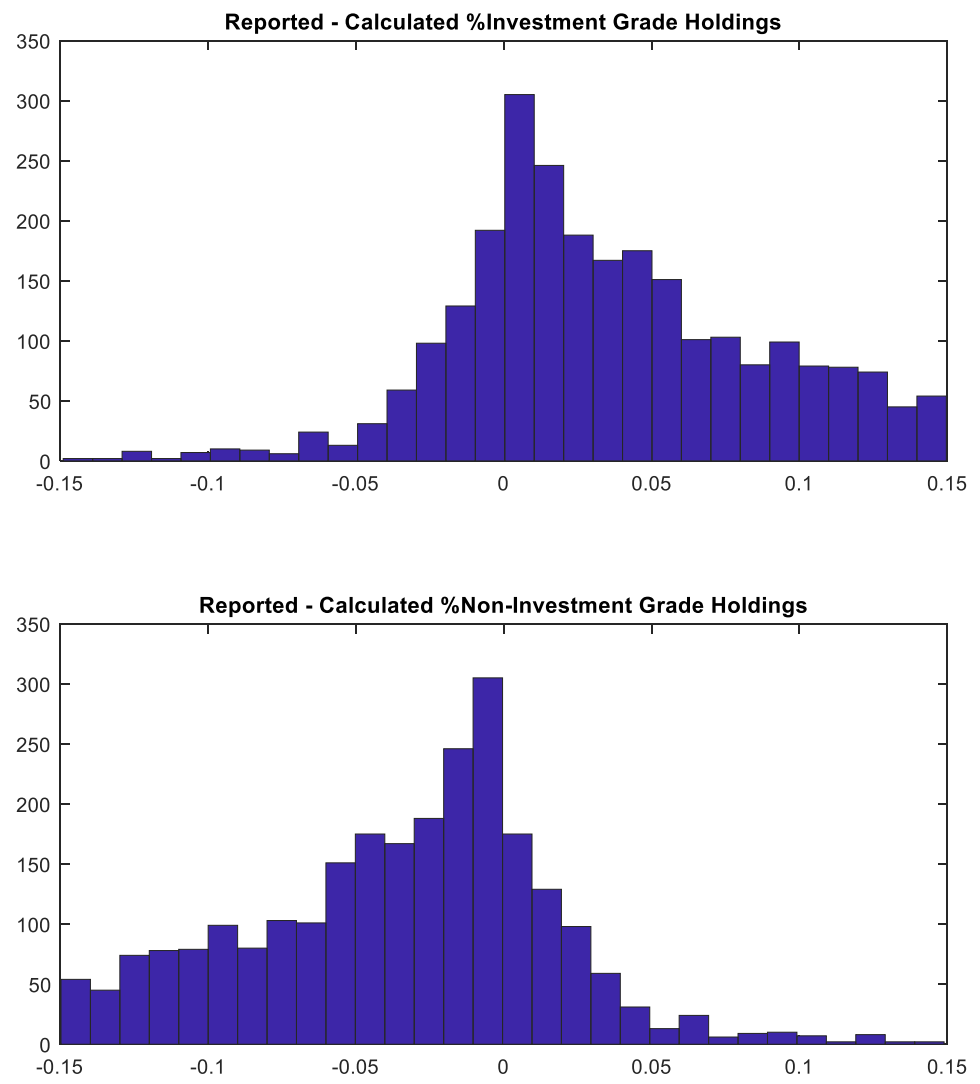

Figure 3. Distribution of Difference between Reported and Calculated Holdings

This graph plots the histograms of fund reported \% holdings minus the calculated \% holdings in the various bond credit rating categories. The sample period begins in Q1 2017, when Morningstar began calculating \% holdings of assets in each credit risk category per each fixed income fund, and ends in Q2 2018. Observations where fund reported \% is exactly the same as the calculated \% holdings are removed to aid readability. 


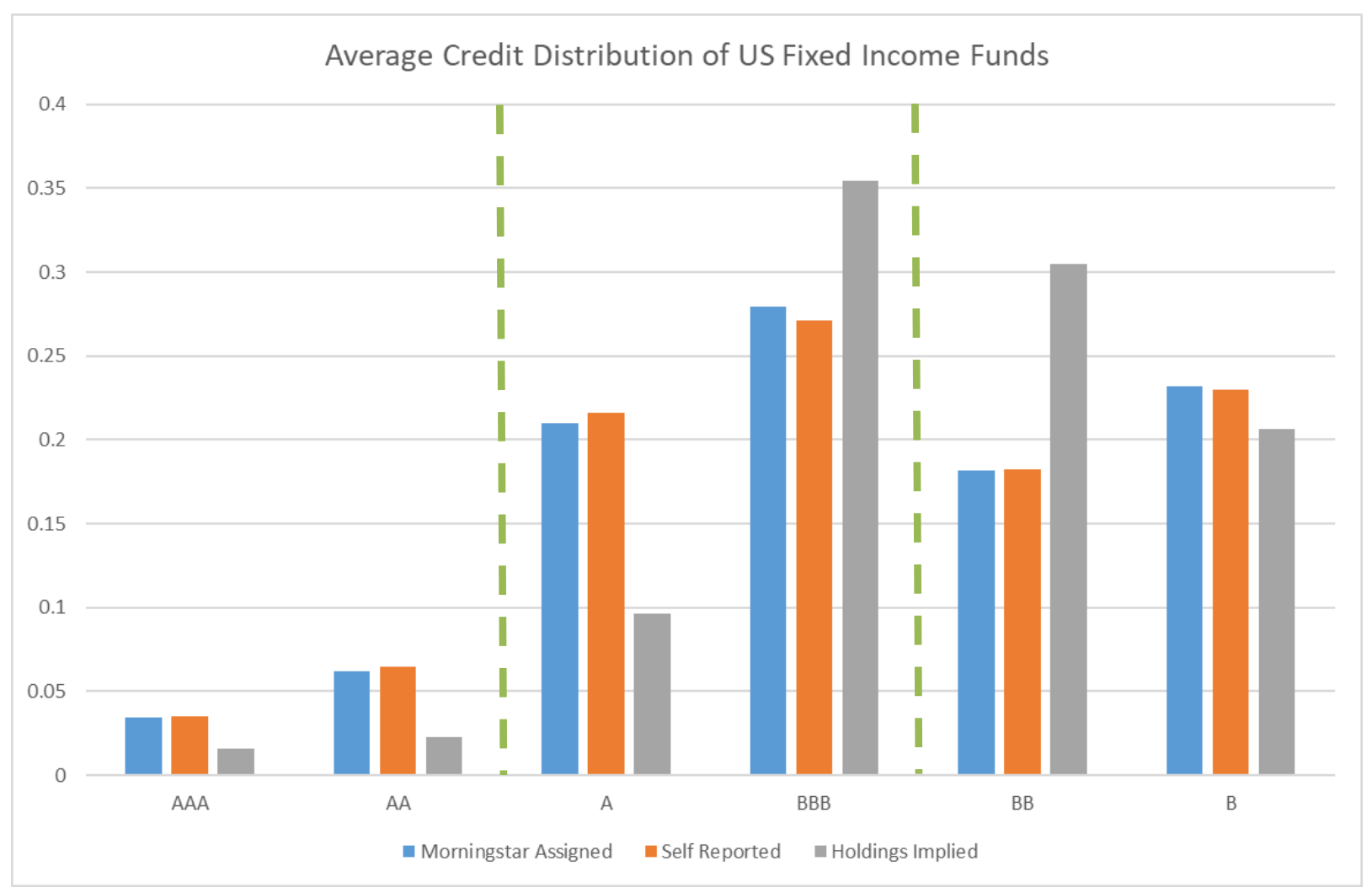

Figure 4. Credit Risk Distribution of US Fixed Income Funds

This figure plots the credit risk distribution of fund-quarter observations between Q1 2017 and Q2 2018. The blue is the distribution of the official average credit quality category that Morningstar assigns to US Fixed Income funds. According to MS's methodology, this official credit quality category is calculated using fund survey reported $\%$ holdings of assets in the various credit risk categories. In red, we replicate the official credit quality category using the fund survey-reported $\%$ holdings. The grey is the counter-factual credit risk category that would result if we had used MS calculated \% holdings. The dashed lines represent breaks in the fixed income fund style-box. AAA and AA credit quality funds are high credit quality; $\mathrm{A}$ and $\mathrm{BBB}$ credit quality funds are medium credit quality; and $\mathrm{BB}$ and $\mathrm{B}$ are low credit quality as deemed by Morningstar. 
Table 1.

Description of Data

We obtain credit ratings from three sources. Dodd-Frank requires all credit rating agencies to release their rating data history through XBRL filings with a one year delay. Capital IQ subscription contains the S\&P rating history. Mergent FISD contains corporates, supranational, and agency/treasuries debts. Portfolio history is directly from Morningstar's collection of filings and surveys for each fund. The surveyed holdings \% on individual fixed income funds comes from the Morningstar Direct database from Q1 2003 to Q2 2018.

Panel A. Sources of Credit Ratings:

\begin{tabular}{lll}
\hline Dates & Source & Coverage Description \\
\hline Jun 2012 to Jun 2018 & XBRL Filing & All NRSROs Rated Bonds \\
Jan 2003 to Jun 2018 & Capital IQ & S\&P Rating History \\
& & $\begin{array}{l}\text { S\&P, Moody's, Fitch Ratings for Corporations and } \\
\text { Jan 2003 to Jun 2018 }\end{array}$ \\
\hline
\end{tabular}

Panel B. Actual Holdings of US Fixed Income Funds from Q1 2003 to Q2 2018

\begin{tabular}{|c|c|c|c|c|c|c|}
\hline & 10th P & Median & 90 th $\mathrm{P}$ & Mean & Std. & $\mathrm{N}$ \\
\hline $\mathrm{AAA}$ & $0.00 \%$ & $40.8 \%$ & $81.4 \%$ & $39.0 \%$ & $31.2 \%$ & 18,508 \\
\hline $\mathrm{AA}$ & $0.00 \%$ & $2.48 \%$ & $9.15 \%$ & $3.73 \%$ & $4.92 \%$ & 18,508 \\
\hline $\mathrm{A}$ & $0.00 \%$ & $7.97 \%$ & $22.7 \%$ & $9.58 \%$ & $9.94 \%$ & 18,508 \\
\hline BBB & $0.326 \%$ & $12.6 \%$ & $35.8 \%$ & $15.9 \%$ & $15.9 \%$ & 18,508 \\
\hline $\mathrm{BB}$ & $0.00 \%$ & $3.88 \%$ & $28.2 \%$ & $9.10 \%$ & $11.6 \%$ & 18,508 \\
\hline B & $0.00 \%$ & $1.52 \%$ & $44.8 \%$ & $11.4 \%$ & $18.3 \%$ & 18,508 \\
\hline Below B & $0.00 \%$ & $0.537 \%$ & $18.1 \%$ & $4.71 \%$ & $8.08 \%$ & 18,508 \\
\hline Unrated & $0.0743 \%$ & $4.12 \%$ & $15.7 \%$ & $6.50 \%$ & $7.42 \%$ & 18,508 \\
\hline
\end{tabular}


Panel C. Surveyed Holdings of US Fixed Income Funds from Q1 2003 to Q2 2018

\begin{tabular}{lcccccc}
\hline & 10th P & Median & 90 th P & Mean & Std. & $\mathrm{N}$ \\
\cline { 2 - 6 } AAA & $0.00 \%$ & $41.1 \%$ & $83.9 \%$ & $40.1 \%$ & $31.5 \%$ & 18,508 \\
AA & $0.00 \%$ & $3.56 \%$ & $12.8 \%$ & $5.51 \%$ & $7.97 \%$ & 18,508 \\
A & $0.00 \%$ & $9.34 \%$ & $25.6 \%$ & $10.9 \%$ & $10.7 \%$ & 18,508 \\
BBB & $0.50 \%$ & $12.5 \%$ & $34.6 \%$ & $15.7 \%$ & $15.1 \%$ & 18,508 \\
\hline BB & $0.00 \%$ & $4.20 \%$ & $32.0 \%$ & $10.3 \%$ & $13.3 \%$ & 18,508 \\
B & $0.00 \%$ & $1.70 \%$ & $46.0 \%$ & $11.8 \%$ & $18.6 \%$ & 18,508 \\
Below B & $0.00 \%$ & $0.39 \%$ & $14.6 \%$ & $3.99 \%$ & $7.16 \%$ & 18,508 \\
Unrated & $0.00 \%$ & $0.32 \%$ & $5.26 \%$ & $1.67 \%$ & $3.61 \%$ & 18,508 \\
\hline
\end{tabular}


Table 2.

\section{Time Series of Misclassification}

In this table, we report the time series of Fund-Quarter observations in each Morningstar Credit Quality Category. The last column is the number of funds that are misclassified into the high or med credit quality category. Morningstar changed the way it calculated average credit quality in August 2010. Prior to August 2010, the average credit quality is a simple weighted average of the underlying linear bond scores, in which a AAA bond has a score of 2, AA has a score of 3, and so on. After August 2010, the credit risk variable attempts to describe a fund in terms of the returns and risks of a portfolio of rated bonds, and nonlinear scores are assigned to each category. The sample is from Q1 2003 to Q2 2018. We record the weighing scheme used after August 2010 in Appendix C.

\begin{tabular}{ccccc}
\hline Year & $\begin{array}{c}\text { High Credit } \\
\text { Quality }\end{array}$ & $\begin{array}{c}\text { Med Credit } \\
\text { Quality }\end{array}$ & $\begin{array}{c}\text { Low Credit } \\
\text { Quality }\end{array}$ & $\begin{array}{c}\# \\
\text { Misclassified }\end{array}$ \\
\hline 2003 & 251 & 412 & 321 & 7 \\
2004 & 262 & 396 & 337 & 4 \\
2005 & 255 & 364 & 282 & 4 \\
2006 & 315 & 414 & 332 & 5 \\
2007 & 322 & 516 & 422 & 7 \\
2008 & 359 & 610 & 468 & 8 \\
2009 & 246 & 698 & 548 & 9 \\
\hline 2010 & 209 & 705 & 583 & 147 \\
2011 & 189 & 765 & 658 & 307 \\
2012 & 194 & 857 & 708 & 283 \\
2013 & 191 & 887 & 824 & 297 \\
2014 & 178 & 920 & 891 & 348 \\
2015 & 181 & 1,056 & 1,022 & 321 \\
2016 & 209 & 1,195 & 1,024 & 360 \\
2017 & 225 & 1,215 & 993 & 370 \\
2018 & 123 & 581 & 484 & 191 \\
\hline
\end{tabular}




\section{Table 3.}

\section{Yields and Misclassification}

In this table, we regress various yield metrics on misclassified dummy and control variables. Misclassified dummy is 1 if the official credit quality (High or Medium) is higher than the counter factual credit quality, and 0 otherwise. Funds voluntarily report their portfolio yields (1) and (4) to Morningstar. Morningstar began calculating the holding yields (2) and (5) in 2017. The 12-month total interest, coupon, and dividend payments constitute the 12-month yield (3) and (6). The sample period is Q3 2010 to Q2 2018. tstatistics are double-clustered by time and fund.

\begin{tabular}{|c|c|c|c|c|c|c|}
\hline & $\begin{array}{c}(1) \\
\text { Reported } \\
\text { Yield }_{t} \\
\end{array}$ & $\begin{array}{c}(2) \\
\text { Calculated } \\
\text { Yield }_{\mathrm{t}} \\
\end{array}$ & $\begin{array}{c}(3) \\
\text { 12-Month } \\
\text { Yield }_{t+11} \\
\end{array}$ & $\begin{array}{c}(4) \\
\text { Reported } \\
\text { Yield }_{t} \\
\end{array}$ & $\begin{array}{c}(5) \\
\text { Calculated } \\
\text { Yield }_{\mathrm{t}} \\
\end{array}$ & $\begin{array}{c}\text { (6) } \\
\text { 12-Month } \\
\text { Yield }_{\mathrm{t}+11} \\
\end{array}$ \\
\hline Misclassified $_{\mathrm{t}-1}$ & $\begin{array}{c}0.277^{* * *} \\
(5.494)\end{array}$ & $\begin{array}{c}0.237^{* * *} \\
(5.372)\end{array}$ & $\begin{array}{c}0.190^{* * *} \\
(3.344)\end{array}$ & $\begin{array}{l}0.0106 \\
(0.157)\end{array}$ & $\begin{array}{l}0.0130 \\
(0.273)\end{array}$ & $\begin{array}{l}-0.0735 \\
(-1.106)\end{array}$ \\
\hline \multirow[t]{2}{*}{ Reported Credit Score $_{t-1}$} & $0.112^{* * *}$ & $0.0569 * * *$ & $0.0551^{* * *}$ & $0.0727^{* * *}$ & $0.0486^{* * *}$ & $0.0552^{* * *}$ \\
\hline & $(8.394)$ & $(6.188)$ & $(4.744)$ & $(7.861)$ & $(9.229)$ & $(6.755)$ \\
\hline Reported Duration $_{\mathrm{t}-1}$ & $\begin{array}{c}0.127^{* * *} \\
(4.263)\end{array}$ & $\begin{array}{c}0.0229 * * \\
(3.083)\end{array}$ & $\begin{array}{c}0.107^{* * *} \\
(3.272)\end{array}$ & $\begin{array}{c}0.138^{* * *} \\
(4.820)\end{array}$ & $\begin{array}{c}0.0359^{* *} \\
(3.116)\end{array}$ & $\begin{array}{c}0.110^{* * *} \\
(3.637)\end{array}$ \\
\hline $\begin{array}{l}\text { Time x Morningstar } \\
\text { Reported Risk Style FE }\end{array}$ & Yes & Yes & Yes & No & No & No \\
\hline $\begin{array}{l}\text { Time x Correct Fund Risk } \\
\text { Style FE }\end{array}$ & No & No & No & Yes & Yes & Yes \\
\hline $\begin{array}{l}\text { Time x Morningstar } \\
\text { Category FE }\end{array}$ & Yes & Yes & Yes & Yes & Yes & Yes \\
\hline Observations & 6,402 & 1,303 & 7,127 & 7,957 & 1,542 & 8,800 \\
\hline Adjusted R-squared & 0.673 & 0.816 & 0.587 & 0.736 & 0.873 & 0.607 \\
\hline
\end{tabular}


Table 4.

\section{Counterfactuals and Misclassification}

In this table, we regress monthly fund returns on misclassified dummy and control variables. Misclassified dummy is 1 if the official credit quality (High or Medium) is higher than the counter factual credit quality, and 0 otherwise. The sample period is Q3 2010 to Q2 2018. t-statistics are clustered quarterly.

(1)

$(2)$

(3)

(4)

Fund Return $_{t}$ Fund Return Fund Return $_{t}$ Fund Return ${ }_{t}$

\begin{tabular}{|c|c|c|c|c|}
\hline Misclassified $_{\mathrm{t}-1}$ & $\begin{array}{c}3.579 * * * \\
(2.951)\end{array}$ & $\begin{array}{c}3.038^{* * *} \\
(3.472)\end{array}$ & $\begin{array}{c}-2.341^{* *} \\
(-2.003)\end{array}$ & $\begin{array}{l}-0.558 \\
(-0.646)\end{array}$ \\
\hline Reported Credit Score $_{t-1}$ & & $\begin{array}{c}0.411^{* *} \\
(2.419)\end{array}$ & & $\begin{array}{l}0.611^{* *} \\
(2.259)\end{array}$ \\
\hline Reported Duration $_{\mathrm{t}-1}$ & & $\begin{array}{c}1.522 \\
(1.065)\end{array}$ & & $\begin{array}{c}1.468 \\
(1.012)\end{array}$ \\
\hline Average Expense $_{t-1}$ & & $\begin{array}{c}-3.551^{* * *} \\
(-3.393)\end{array}$ & & $\begin{array}{c}-3.392^{* * *} \\
(-3.774)\end{array}$ \\
\hline $\begin{array}{l}\text { Time x Morningstar } \\
\text { Reported Risk Style FE }\end{array}$ & Yes & Yes & No & No \\
\hline $\begin{array}{l}\text { Time x Correct Fund Risk } \\
\text { Style FE }\end{array}$ & No & No & Yes & Yes \\
\hline $\begin{array}{l}\text { Time x Morningstar } \\
\text { Category FE }\end{array}$ & Yes & Yes & Yes & Yes \\
\hline Observations & 25,318 & 22,671 & 31,196 & 27,941 \\
\hline Adjusted R-squared & 0.874 & 0.874 & 0.841 & 0.844 \\
\hline
\end{tabular}


Table 5.

Morningstar Star Ratings and Misclassification

In this table, we regress Morningstar ratings on the misclassified dummy and controls. Since the ratings and expenses are reported at the share class level, the fund level Morningstar Ratings and the Average Expense ratio are calculated as the value weighted average of their respective share-class level values. The sample period is Q3 2010 to Q2 2018. t-statistics are double-clustered by time and fund.

\begin{tabular}{|c|c|c|c|c|}
\hline & $\begin{array}{c}(1) \\
\text { Morningstar } \\
\text { Rating } \\
3 \mathrm{Yr}_{\mathrm{t}} \\
\end{array}$ & $\begin{array}{c}(2) \\
\text { Morningstar } \\
\text { Rating } \\
3 \mathrm{Yr}_{\mathrm{t}} \\
\end{array}$ & $\begin{array}{c}(3) \\
\text { Morningstar } \\
\text { Rating } \\
\text { Overall }_{\mathrm{t}} \\
\end{array}$ & $\begin{array}{c}(4) \\
\text { Morningstar } \\
\text { Rating } \\
\text { Overall }_{\mathrm{t}} \\
\end{array}$ \\
\hline Misclassified $_{\mathrm{t}-1}$ & $\begin{array}{c}0.383^{* * *} \\
(5.971)\end{array}$ & $\begin{array}{c}0.170^{* * *} \\
(3.774)\end{array}$ & $\begin{array}{c}0.341^{* * *} \\
(4.660)\end{array}$ & $\begin{array}{c}0.182^{* * *} \\
(3.218)\end{array}$ \\
\hline Reported Credit Score ${ }_{t-1}$ & $\begin{array}{c}0.0698^{* * *} \\
(4.355)\end{array}$ & $\begin{array}{c}0.0299^{* *} \\
(2.553)\end{array}$ & $\begin{array}{c}0.0588^{* * *} \\
(3.090)\end{array}$ & $\begin{array}{l}0.0289^{*} \\
(1.774)\end{array}$ \\
\hline Reported Duration $_{\mathrm{t}-1}$ & $\begin{array}{c}0.107^{* * *} \\
(3.679)\end{array}$ & $\begin{array}{l}-0.0277 \\
(-1.138)\end{array}$ & $\begin{array}{c}0.113^{* * *} \\
(2.752)\end{array}$ & $\begin{array}{l}0.0122 \\
(0.386)\end{array}$ \\
\hline Average Expenses $\mathrm{E}_{\mathrm{t}-1}$ & $\begin{array}{c}-1.024^{* * *} \\
(-6.915)\end{array}$ & $\begin{array}{c}-0.755^{* * *} \\
(-6.966)\end{array}$ & $\begin{array}{c}-0.822^{* * *} \\
(-5.045)\end{array}$ & $\begin{array}{c}-0.622^{* * *} \\
(-4.566)\end{array}$ \\
\hline 3 Year Returns $\mathrm{t}_{\mathrm{t}-1}$ & & $\begin{array}{c}15.22^{* * *} \\
(8.036)\end{array}$ & & $\begin{array}{c}11.36^{* * *} \\
(6.202)\end{array}$ \\
\hline $\begin{array}{l}\text { Time x Morningstar Reported } \\
\text { Risk Style FE }\end{array}$ & Yes & Yes & Yes & Yes \\
\hline $\begin{array}{l}\text { Time x Morningstar Category } \\
\text { FE }\end{array}$ & Yes & Yes & Yes & Yes \\
\hline Observations & 7,391 & 7,391 & 7,391 & 7,391 \\
\hline Adjusted R-squared & 0.211 & 0.541 & 0.170 & 0.373 \\
\hline
\end{tabular}




\section{Table 6. \\ Expense Ratios and Misclassification}

In this table, we analyze whether misclassified funds are more expensive than usual. We regress average expense ratio on misclassified dummy and control variables. The average expense ratio is calculated at the fund level as the value weighted average of their respective share-class level values. The sample period is Q3 2010 to Q2 2018. t-statistics are double-clustered by time and fund.

\begin{tabular}{|c|c|c|c|}
\hline & $\begin{array}{c}(1) \\
\text { Average } \\
\text { Expense }_{\mathrm{t}}\end{array}$ & $\begin{array}{c}(2) \\
\text { Average } \\
\text { Expense }_{\mathrm{t}}\end{array}$ & $\begin{array}{c}(3) \\
\text { Average } \\
\text { Expense }\end{array}$ \\
\hline Misclassified $_{\mathrm{t}-1}$ & $\begin{array}{c}0.114^{* * *} \\
(6.356)\end{array}$ & $\begin{array}{c}0.0765^{* * *} \\
(4.186)\end{array}$ & $\begin{array}{c}0.0760^{* * *} \\
(4.172)\end{array}$ \\
\hline Reported Credit Score $_{t-1}$ & & $\begin{array}{c}0.0224^{* * *} \\
(3.611)\end{array}$ & $\begin{array}{c}0.0222^{* * * *} \\
(3.592)\end{array}$ \\
\hline Reported Duration $_{\mathrm{t}-1}$ & & & $\begin{array}{r}-0.00790 \\
(-0.754)\end{array}$ \\
\hline $\begin{array}{l}\text { Time x Morningstar } \\
\text { Reported Risk Style FE }\end{array}$ & Yes & Yes & Yes \\
\hline $\begin{array}{l}\text { Time x Morningstar } \\
\text { Category FE }\end{array}$ & Yes & Yes & Yes \\
\hline Observations & 8,373 & 7,586 & 7,586 \\
\hline Adjusted R-squared & 0.125 & 0.153 & 0.154 \\
\hline
\end{tabular}




\section{Table 7. \\ Fund Flows and Misclassification}

In this table, we regress whether investor in net contributed cash-flows into funds and share classes as related to lagged fund misclassifications. There are two specifications for fund level regressions in columns (1) and (2). The first column regresses flow indicator on misclassified dummy directly. The second column regresses the flow indicator on misclassified stars. We separately regress the flow indicator at the share-class level for institutional (3), retail (4), and retirement (5) classes against the misclassified dummy. The sample period is Q3 2010 to Q2 2018. t-statistics are clustered quarterly.

\begin{tabular}{|c|c|c|c|c|c|}
\hline & (1) & $(2)$ & (3) & (4) & (5) \\
\hline & Fund & tfolio & $\begin{array}{l}\text { Institutional } \\
\text { Share Class }\end{array}$ & $\begin{array}{c}\text { Retail } \\
\text { Share Class }\end{array}$ & $\begin{array}{l}\text { Retirement } \\
\text { Share Class }\end{array}$ \\
\hline & Flow $_{t}>0$ & Flow $_{t}>0$ & Flow $_{t}>0$ & Flow $_{t}>0$ & Flow $_{t}>0$ \\
\hline Misclassified $_{t-1}$ & $\begin{array}{c}0.0637^{* * *} \\
(4.947)\end{array}$ & & $\begin{array}{c}0.0639^{* * *} \\
(3.639)\end{array}$ & $\begin{array}{c}0.0905^{* * *} \\
(4.368)\end{array}$ & $\begin{array}{c}0.129^{* * *} \\
(5.356)\end{array}$ \\
\hline Misclassified Stars $_{t}$ & & $\begin{array}{c}0.171^{* * *} \\
(5.155)\end{array}$ & & & \\
\hline Reported Credit Score ${ }_{t-1}$ & $\begin{array}{c}0.00438 \\
(1.198)\end{array}$ & $\begin{array}{c}-0.00422 \\
(-0.757)\end{array}$ & $\begin{array}{c}0.00736^{*} \\
(1.864)\end{array}$ & $\begin{array}{c}-0.00435 \\
(-0.945)\end{array}$ & $\begin{array}{c}-0.0117^{* * *} \\
(-2.906)\end{array}$ \\
\hline Reported Duration $_{\mathrm{t}-1}$ & $\begin{array}{c}0.0191 * * * \\
(3.998)\end{array}$ & $\begin{array}{l}0.00201 \\
(0.261)\end{array}$ & $\begin{array}{c}0.0145^{* * *} \\
(2.855)\end{array}$ & $\begin{array}{l}0.00537 \\
(0.388)\end{array}$ & $\begin{array}{c}-0.0259^{* *} \\
(-2.590)\end{array}$ \\
\hline Average Expenses $\mathrm{E}_{\mathrm{t}-1}$ & $\begin{array}{c}-0.238^{* * *} \\
(-7.431)\end{array}$ & $\begin{array}{l}-0.0685 \\
(-1.409)\end{array}$ & $\begin{array}{c}-0.160^{* * *} \\
(-4.776)\end{array}$ & $\begin{array}{c}-0.204^{* * *} \\
(-5.826)\end{array}$ & $\begin{array}{c}-0.104^{* *} \\
(-2.159)\end{array}$ \\
\hline $\begin{array}{l}\text { Time x Morningstar } \\
\text { Reported Risk Style FE }\end{array}$ & Yes & Yes & Yes & Yes & Yes \\
\hline $\begin{array}{l}\text { Time x Morningstar } \\
\text { Category FE }\end{array}$ & Yes & Yes & Yes & Yes & Yes \\
\hline Observations & 7,766 & 7,391 & 7,248 & 4,306 & 5,733 \\
\hline Adjusted R-squared & 0.068 & 0.086 & 0.048 & 0.079 & 0.019 \\
\hline
\end{tabular}


Table 8.

Characteristics of Misclassified Funds

In this table, we regress whether a bond fund is misclassified against various contemporaneous fund characteristics. New Fund indicates whether a fund has less than three years of history. $\log$ Size is the log of total fund level AUM. The number of fund managers (Number of Managers) and their average tenure lengths (Average Tenure Length) are calculated using Morningstar Direct. Only Taxable Bond Fund indicates whether a fund is the only taxable bond fund present within a fund family. This is calculated by matching a fund to its family history information in the CRSP mutual fund database. The number of share classes (Number of Share Classes) is calculated from data provided by Morningstar Direct. Market Share is a fund's AUM as a percent of the total AUM placed in all funds of a respective Morningstar Category. Past 3 Year Returns is a fund's past 3 year value weighted net returns of its respective share classes. The sample period is Q3 2010 to Q2 2018. t-statistics are clustered quarterly.

\begin{tabular}{|c|c|c|c|}
\hline & $\begin{array}{c}(1) \\
\text { Misclassified }\end{array}$ & $\begin{array}{c}(2) \\
\text { Misclassified }\end{array}$ & $\begin{array}{c}(3) \\
\text { Misclassified }\end{array}$ \\
\hline New Fund & $\begin{array}{c}0.0668^{* * *} \\
(3.834)\end{array}$ & $\begin{array}{c}0.0785^{* * *} \\
(4.257)\end{array}$ & $\begin{array}{c}0.161^{* * *} \\
(5.673)\end{array}$ \\
\hline Log Size & $\begin{array}{l}0.0363^{* * *} \\
(7.484)\end{array}$ & $\begin{array}{c}0.0132^{* *} \\
(2.294)\end{array}$ & $\begin{array}{c}0.00921 \\
(1.628)\end{array}$ \\
\hline Average Tenure Length & $\begin{array}{c}-0.000263^{* *} \\
(-2.054)\end{array}$ & $\begin{array}{c}-0.000232 \\
(-1.647)\end{array}$ & $\begin{array}{c}-0.000350 * * * \\
(-2.829)\end{array}$ \\
\hline Number of Managers & $\begin{array}{c}0.000937 \\
(0.490)\end{array}$ & $\begin{array}{l}0.00589^{* *} \\
(2.662)\end{array}$ & $\begin{array}{r}0.00347 \\
(1.506)\end{array}$ \\
\hline Number of Share Classes & $\begin{array}{l}0.0185^{* * *} \\
(11.81)\end{array}$ & $\begin{array}{l}0.0150^{* * *} \\
(10.34)\end{array}$ & $\begin{array}{l}0.0152^{* * *} \\
(9.867)\end{array}$ \\
\hline Only Taxable Bond Fund & $\begin{array}{c}0.0331^{* *} \\
(2.357)\end{array}$ & $\begin{array}{c}0.0263^{*} \\
(1.947)\end{array}$ & $\begin{array}{c}0.0361^{* *} \\
(2.500)\end{array}$ \\
\hline Market Share & $\begin{array}{c}-0.906^{* * *} \\
(-3.143)\end{array}$ & $\begin{array}{c}1.548^{* * *} \\
(2.842)\end{array}$ & $\begin{array}{c}1.766^{* * *} \\
(3.273)\end{array}$ \\
\hline Past 3 Year Returns & & & $\begin{array}{c}1.650^{* * *} \\
(6.834)\end{array}$ \\
\hline Time FE & Yes & No & No \\
\hline $\begin{array}{l}\text { Time x Morningstar Reported Risk } \\
\text { Style FE }\end{array}$ & No & Yes & Yes \\
\hline Time x Morningstar Category FE & No & Yes & Yes \\
\hline $\begin{array}{l}\text { Observations } \\
\text { Adjusted R-squared }\end{array}$ & $\begin{array}{l}7,612 \\
0.030\end{array}$ & $\begin{array}{l}7,543 \\
0.155\end{array}$ & $\begin{array}{l}7,543 \\
0.178\end{array}$ \\
\hline
\end{tabular}




\section{Table 9. \\ Further Determinants of Misclassifying over Time, Geographic Location, and across Families}

In the following tables, we explore further determinants of misclassification. The sample period is Q3 2010 to Q2 2018. In Panel A, we explore how a fund starts and ends misclassifying their holdings are related to various characteristics. In column (1), the left-hand side variable is an indicator that represents when a previously correctly classified fund starts misclassifying. In column (2), the left-hand side variable is an indicator for when a previously misclassified fund starts correctly classifying. In column 3, we regress (1) minus (2). New Fund indicates whether a fund has less than three years of history. Log Size is the log of total fund level AUM. The number of fund managers (Number of Managers) and their average tenure lengths (Average Tenure Length) are calculated using Morningstar Direct. Only Taxable Bond Fund indicates whether a fund is the only taxable bond fund present within a fund family. This is calculated by matching a fund to its family history information in the CRSP mutual fund database. The number of share classes (Number of Share Classes) is calculated from data provided by Morningstar Direct. Market Share is a fund's AUM as a percent of the total AUM placed in all funds of a respective Morningstar Category. Past 3 Year Returns is a fund's past 3-year value weighted net returns of its respective share classes. In Panel $\mathrm{B}$, we regress the misclassification indicator against controls, category fixed effects, and additionally geographic indicators. Northwest, West, South, and Midwest correspond to U.S. Census Bureau statistical regions. In Panel C, we regress the misclassification indicator against Time, Fund Family, and Fund Fixed Effects. t-statistics are clustered quarterly.

\section{Panel A. Characteristics of Misclassified Funds}

\begin{tabular}{|c|c|c|c|}
\hline & $\begin{array}{c}1) \\
\text { Start Being } \\
\text { Misclassified } \\
\end{array}$ & $\begin{array}{c}(2) \\
\text { End Being } \\
\text { Misclassified } \\
\end{array}$ & $\begin{array}{c}(3) \\
\text { (Start-End) } \\
\text { Misclassified } \\
\end{array}$ \\
\hline New Fund & $\begin{array}{c}-0.00665 \\
(-0.684)\end{array}$ & $\begin{array}{c}0.00366 \\
(0.255)\end{array}$ & $\begin{array}{l}-0.0103 \\
(-0.534)\end{array}$ \\
\hline Log Size & $\begin{array}{l}0.00174 \\
(0.553)\end{array}$ & $\begin{array}{c}-0.00228 \\
(-0.685)\end{array}$ & $\begin{array}{c}0.00402 \\
(0.912)\end{array}$ \\
\hline Average Tenure Length & $\begin{array}{c}-0.000128^{* * *} \\
(-2.927)\end{array}$ & $\begin{array}{c}-0.000142^{* * *} \\
(-2.947)\end{array}$ & $\begin{array}{c}1.38 \mathrm{e}-05 \\
(0.197)\end{array}$ \\
\hline Number of Managers & $\begin{array}{c}0.000885 \\
(0.747)\end{array}$ & $\begin{array}{l}0.00335^{* *} \\
(2.349)\end{array}$ & $\begin{array}{r}-0.00247 \\
(-1.478)\end{array}$ \\
\hline Number of Share Classes & $\begin{array}{c}0.00294^{* * *} \\
(2.843)\end{array}$ & $\begin{array}{l}0.00341^{* * *} \\
(3.767)\end{array}$ & $\begin{array}{c}-0.000475 \\
(-0.326)\end{array}$ \\
\hline Only Taxable Bond Fund & $\begin{array}{c}0.00445 \\
(0.589)\end{array}$ & $\begin{array}{c}-0.00588 \\
(-0.651)\end{array}$ & $\begin{array}{l}0.0103 \\
(0.857)\end{array}$ \\
\hline Market Share & $\begin{array}{c}0.454 \\
(0.820)\end{array}$ & $\begin{array}{l}1.010 \\
(1.513)\end{array}$ & $\begin{array}{l}-0.557 \\
(-0.538)\end{array}$ \\
\hline Past 3-Year Returns & $\begin{array}{c}-0.0738^{*} \\
(-1.820)\end{array}$ & $\begin{array}{c}0.186^{* *} \\
(2.193)\end{array}$ & $\begin{array}{c}-0.260^{* *} \\
(-2.731)\end{array}$ \\
\hline $\begin{array}{l}\text { Time x Morningstar } \\
\text { Reported Risk Style FE }\end{array}$ & Yes & Yes & Yes \\
\hline $\begin{array}{l}\text { Time x Morningstar } \\
\text { Category FE }\end{array}$ & Yes & Yes & Yes \\
\hline Observations & 7,941 & 7,941 & 7,941 \\
\hline Adjusted R-squared & 0.004 & 0.028 & 0.011 \\
\hline
\end{tabular}


Panel B. Geography of Misclassification

\begin{tabular}{lc}
\hline & $\begin{array}{c}(1) \\
\text { Northeast }\end{array}$ \\
\cline { 2 - 2 } West & - \\
& -0.0115 \\
South & $(-0.727)$ \\
& $0.0677^{* * *}$ \\
Midwest & $(5.025)$ \\
& -0.0177 \\
& $(-1.655)$ \\
Controls & Yes \\
Time x Morningstar & Yes \\
Reported Risk Style FE & \\
Time x Morningstar & Yes \\
Category FE & \\
& \\
Observations & 6,774 \\
Adjusted R-squared & 0.153 \\
\hline
\end{tabular}

Panel C. Misclassification and Fund Family Fixed Effects

\begin{tabular}{|c|c|c|c|}
\hline & $\begin{array}{c}(1) \\
\text { Misclassified }\end{array}$ & $\begin{array}{c}(2) \\
\text { Misclassified }\end{array}$ & $\begin{array}{c}(3) \\
\text { Misclassified }\end{array}$ \\
\hline Time FE & Yes & Yes & Yes \\
\hline Family FE & No & Yes & Yes \\
\hline Fund FE & No & No & Yes \\
\hline Observations & 6,923 & 6,919 & 6,906 \\
\hline Adjusted R-squared & 0.003 & 0.227 & 0.494 \\
\hline
\end{tabular}


Table 10.

\section{The Characteristics of Unrated Bonds held by Funds}

This table summarizes the corporate bonds in the Mergent FISD database that were issued between 2010 and 2016. Each box describes the mean offering yield and the number of bonds in different ranges of offering maturities and credit qualities. A bond's credit rating at issuance is the Barclays/Bloomberg composite of Fitch, Moody's, and S\&P's respective ratings that were available within 30 trading days of the offering date. $\mathrm{N}$ is the number of issue observations in each box.

\begin{tabular}{|c|c|c|c|}
\hline \multirow[b]{3}{*}{$\begin{array}{l}\text { High Investment } \\
\text { Grade (AA to AAA) }\end{array}$} & \multicolumn{3}{|c|}{ Issuing Maturity } \\
\hline & 0 to 3.5 Years & 3.5 to 6 Years & 6 to 10 Years \\
\hline & $\begin{array}{c}1.44 \% \\
\mathrm{~N}=113\end{array}$ & $\begin{array}{l}2.21 \% \\
\mathrm{~N}=146\end{array}$ & $\begin{array}{l}2.70 \% \\
\mathrm{~N}=33\end{array}$ \\
\hline $\begin{array}{l}\text { Medium Investment } \\
\text { Grade (BBB to A) }\end{array}$ & $\begin{array}{c}1.75 \% \\
\mathrm{~N}=483\end{array}$ & $\begin{array}{c}2.80 \% \\
\mathrm{~N}=1,110\end{array}$ & $\begin{array}{l}3.75 \% \\
\mathrm{~N}=370\end{array}$ \\
\hline $\begin{array}{l}\text { Junk Grade Bonds } \\
\text { (BB and Below) }\end{array}$ & $\begin{array}{l}5.14 \% \\
\mathrm{~N}=43\end{array}$ & $\begin{array}{l}8.08 \% \\
\mathrm{~N}=563\end{array}$ & $\begin{array}{c}7.69 \% \\
\mathrm{~N}=1,655\end{array}$ \\
\hline Unrated Bonds & $\begin{array}{l}7.81 \% \\
\mathrm{~N}=81\end{array}$ & $\begin{array}{c}6.43 \% \\
\mathrm{~N}=245\end{array}$ & $\begin{array}{c}7.09 \% \\
\mathrm{~N}=356\end{array}$ \\
\hline
\end{tabular}


Table 11.

Misclassified Fund Performance around Junk Bond Crashes (and Outperformance)

In this table, we regress monthly fund returns on misclassified dummy and control variables. Misclassified dummy is 1 if the official credit quality (High or Medium) is higher than the counter factual credit quality, and 0 otherwise. In the columns, we regress separately the sample months when JNK, the SPDR Bloomberg Barclays High Yield Bond ETF, had major negative returns (1), close to 0 returns (2), and substantial positive returns (3). The sample period is Q3 2010 to Q2 2018. t-statistics are clustered quarterly.

\begin{tabular}{|c|c|c|c|}
\hline & $\begin{array}{c}(1) \\
\text { Fund Return } \\
\text { JNK }<-1 \%\end{array}$ & $\begin{array}{c}(2) \\
\text { Fund Return } \\
-1 \%<\text { JNK }<1 \% \\
\end{array}$ & $\begin{array}{c}(3) \\
\text { Fund Return } \\
\text { JNK }>1 \% \\
\end{array}$ \\
\hline Misclassified $_{\mathrm{t}-1}$ & $\begin{array}{c}-4.672^{* * *} \\
(-3.117)\end{array}$ & $\begin{array}{c}2.849^{* *} \\
(2.270)\end{array}$ & $\begin{array}{c}7.630^{* * *} \\
(6.141)\end{array}$ \\
\hline $\begin{array}{l}\text { Reported Credit } \\
\text { Score }_{t-1}\end{array}$ & $\begin{array}{l}-1.421^{* *} \\
(-2.270)\end{array}$ & $\begin{array}{c}0.263 \\
(0.828)\end{array}$ & $\begin{array}{c}2.024^{* * *} \\
(5.232)\end{array}$ \\
\hline Reported Duration $_{\mathrm{t}-1}$ & $\begin{array}{l}-4.784 \\
(-1.246)\end{array}$ & $\begin{array}{c}0.378 \\
(0.187)\end{array}$ & $\begin{array}{l}5.227^{* *} \\
(2.327)\end{array}$ \\
\hline Average Expense $_{t-1}$ & $\begin{array}{c}-9.683^{* * *} \\
(-3.457)\end{array}$ & $\begin{array}{l}-2.234^{*} \\
(-2.011)\end{array}$ & $\begin{array}{l}-1.146 \\
(-0.945)\end{array}$ \\
\hline $\begin{array}{l}\text { Time x Morningstar } \\
\text { Reported Risk Style } \\
\text { FE } \\
\text { Time x Morningstar } \\
\text { Category FE }\end{array}$ & Yes & Yes & Yes \\
\hline $\begin{array}{l}\text { Observations } \\
\text { Adjusted R-squared }\end{array}$ & $\begin{array}{l}4,522 \\
0.855\end{array}$ & $\begin{array}{l}9,972 \\
0.879\end{array}$ & $\begin{array}{l}8,177 \\
0.820\end{array}$ \\
\hline
\end{tabular}




\title{
Online Appendix
}

\author{
Don't Take Their Word For It: \\ The Misclassification of Bond Mutual Funds
}




\section{Appendix A: Variable Definitions}

\begin{tabular}{|c|c|c|}
\hline Variable Name & Definition & Data Source \\
\hline Reported AAA \% & $\%$ of holdings in AAA assets as reported by a fund & $\begin{array}{l}\text { Morningstar } \\
\text { Direct }\end{array}$ \\
\hline Calculated AAA \% & $\begin{array}{l}\% \text { of holdings in AAA assets as calculated by } \\
\text { Morningstar }\end{array}$ & $\begin{array}{l}\text { Morningstar } \\
\text { Direct }\end{array}$ \\
\hline AAA $\%$ & $\begin{array}{l}\% \text { of holdings in AAA assets as calculated by us } \\
\text { from the portfolio }\end{array}$ & Constructed \\
\hline$\cdots$ & $\cdots$ & $\cdots$ \\
\hline $\begin{array}{l}\text { Morningstar } \\
\text { Reported Risk Style }\end{array}$ & $\begin{array}{l}\text { A fixed fund could be categorized as any of the } \\
\text { following: } \\
\text { "High Limited", "Medium Limited", "Low } \\
\text { Limited", } \\
\text { "High Moderate", "Medium Moderate", "Low } \\
\text { Moderate", "High Extensive", "Medium Extensive", } \\
\text { and "Low Extensive" }\end{array}$ & $\begin{array}{l}\text { Morningstar } \\
\text { Direct }\end{array}$ \\
\hline $\begin{array}{l}\text { Correct Fund Risk } \\
\text { Style }\end{array}$ & $\begin{array}{l}\text { We re-evaluate a fund as either high, medium, or } \\
\text { low credit quality using their holdings. This } \\
\text { counterfactual fund style is the fund style as } \\
\text { indicated by the re-evaluated credit quality. }\end{array}$ & Constructed \\
\hline Misclassified Dummy & $\begin{array}{l}\text { Dummy variable that indicates whether a fund is } \\
\text { misclassified in their fund credit quality dimension. } \\
\text { It is } 1 \text { if the official credit style (High or Medium) is } \\
\text { higher than the counter factual credit quality as } \\
\text { indicated by holdings, and } 0 \text { otherwise. }\end{array}$ & Constructed \\
\hline $\begin{array}{l}\text { Morningstar } \\
\text { Category }\end{array}$ & $\begin{array}{l}\text { Morningstar's categorization of mutual funds based } \\
\text { on the types of assets owned. See Appendix D for } \\
\text { the various categories included in the sample. }\end{array}$ & $\begin{array}{l}\text { Morningstar } \\
\text { Direct }\end{array}$ \\
\hline $\begin{array}{l}\text { Reported Credit } \\
\text { Score }\end{array}$ & $\begin{array}{l}\text { Default scores calculated using the reported \% asset } \\
\text { holdings using Morningstar's credit risk model } \\
\text { formula (Appendix B) }\end{array}$ & Constructed \\
\hline Reported Duration & The reported effective duration of a portfolio & $\begin{array}{l}\text { Morningstar } \\
\text { Direct }\end{array}$ \\
\hline Reported Yield & $\begin{array}{l}\text { The reported yield to maturity of a portfolio (in \% } \\
\text { points) }\end{array}$ & $\begin{array}{l}\text { Morningstar } \\
\text { Direct }\end{array}$ \\
\hline Calculated Yield & $\begin{array}{l}\text { Morningstar calculated average yield to maturity of } \\
\text { a portfolio (in } \% \text { points) }\end{array}$ & $\begin{array}{l}\text { Morningstar } \\
\text { Direct }\end{array}$ \\
\hline 12-Month Yield & $\begin{array}{l}\text { The total coupon and dividend payment from the } \\
\text { past } 12 \text { months (in } \% \text { points) }\end{array}$ & $\begin{array}{l}\text { Morningstar } \\
\text { Direct }\end{array}$ \\
\hline
\end{tabular}


Fund Return

Morningstar Rating

$3-\mathrm{yr}$

Morningstar Rating

General

Average Expense

Monthly Flow

Flow

JNK
The fund return is the value weighted average of the share class returns. Share class returns come from Constructed Morningstar Direct

The fund level Morningstar Rating is the value weighted average of share level Morningstar Ratings

Constructed

The fund level Morningstar Rating is the value weighted average of share level Morningstar Ratings

Constructed Average expense at the fund level is calculated by taking the value weighted average of the share-class level expense ratios

Monthly fund level investor flows

Morningstar

Direct

Quarterly fund level investor flow is the quarterly sum of monthly flow

Constructed Monthly returns of SPDR Bloomberg Barclays High Yield Bond ETF 


\section{Appendix B: Credit Risk of a Fund Portfolio}

Morningstar defines a bond portfolio's average credit risk using a weighted average score using the credit rating of the underlying assets. Prior to August 2010, a bond asset's score is defined using the following table:

\begin{tabular}{|l|l|l|l|l|l|l|l|l|l|}
\hline $\begin{array}{l}\text { Bond } \\
\text { Quality }\end{array}$ & AAA & AA & A & BBB & BB & B & $\begin{array}{l}\text { Below } \\
\text { B }\end{array}$ & $\begin{array}{l}\text { Not } \\
\text { Rated }\end{array}$ & $\begin{array}{l}\text { Not } \\
\text { Rated } \\
\text { Muni }\end{array}$ \\
\hline Score & 2 & 3 & 4 & 5 & 6 & 7 & 8 & 7 & 6 \\
\hline
\end{tabular}

The portfolio's average position size weighted score then defines its credit quality using the following breakpoints.

\begin{tabular}{|l|l|l|l|l|l|l|l|}
\hline $\begin{array}{l}\text { Portfolio } \\
\text { Average } \\
\text { Score }\end{array}$ & 0 to 2.5 & $\begin{array}{l}2.5 \text { to } \\
3.5\end{array}$ & $\begin{array}{l}3.5 \text { to } \\
4.5\end{array}$ & $\begin{array}{l}4.5 \text { to } \\
5.5\end{array}$ & $\begin{array}{l}5.5 \text { to } \\
6.5\end{array}$ & $\begin{array}{l}6.5 \text { to } \\
7.5\end{array}$ & $>7.5$ \\
\hline $\begin{array}{l}\text { Quality } \\
\text { Rating }\end{array}$ & AAA & AA & A & BBB & BB & B & Below B \\
\hline $\begin{array}{l}\text { Fund } \\
\text { Style } \\
\text { Quality }\end{array}$ & High & High & Medium & Medium & Low & Low & Low \\
\hline
\end{tabular}

After August 2010, the scores are based on a relative default rate:

\begin{tabular}{|l|l|l|l|l|l|l|l|l|l|}
\hline $\begin{array}{l}\text { Bond } \\
\text { Quality }\end{array}$ & AAA & AA & A & BBB & BB & B & $\begin{array}{l}\text { Below } \\
\text { B }\end{array}$ & $\begin{array}{l}\text { Not } \\
\text { Rated }\end{array}$ & $\begin{array}{l}\text { Not } \\
\text { Rated } \\
\text { Muni }\end{array}$ \\
\hline Score & 0 & 0.56 & 2.22 & 5.00 & 17.78 & 49.44 & 100.00 & 49.44 & 17.78 \\
\hline
\end{tabular}

The respective breakpoints for post August 2010 are then:

\begin{tabular}{|l|l|l|l|l|l|l|l|}
\hline $\begin{array}{l}\text { Portfolio } \\
\text { Average } \\
\text { Score }\end{array}$ & 0.13889 & $\begin{array}{l}0.13889 \\
\text { to } \\
1.25000\end{array}$ & $\begin{array}{l}1.25000 \\
\text { to } \\
3.47223\end{array}$ & $\begin{array}{l}3.47223 \\
\text { to } \\
9.02778\end{array}$ & $\begin{array}{l}9.02778 \\
\text { to } \\
31.25000\end{array}$ & $\begin{array}{l}31.25000 \\
\text { to }\end{array}$ & $\begin{array}{l}\geq \\
72.36112\end{array}$ \\
\hline $\begin{array}{l}\text { Quality } \\
\text { Rating }\end{array}$ & AAA & AA & A & BBB & BB & B & Below B \\
\hline $\begin{array}{l}\text { Fund } \\
\begin{array}{l}\text { Style } \\
\text { Quality }\end{array}\end{array}$ & High & High & Medium & Medium & Low & Low & Low \\
\hline
\end{tabular}




\section{Appendix C: Credit Rating Composites}

The following table lists the assumption used for our analysis and the subsequent $\%$ misclassified bond funds in the High and Medium credit quality categories from Q1 2017 to Q2 2018 in our final sample.

\begin{tabular}{|l|c|}
\hline \multicolumn{1}{|c|}{ Assumptions in Classifying Bond Funds } & $\begin{array}{c}\text { \% Fund-Quarter Obs. } \\
\text { Misclassified Between Q1 2017 } \\
\text { and Q2 2018 }\end{array}$ \\
\hline 1) $\begin{array}{l}\text { Use Morningstar's Calculated \% Composition for each } \\
\text { bond fund portfolio. }\end{array}$ & $31.4 \%$ \\
\hline 1) & Calculate \% composition directly using the \\
Bloomberg/Barclays Method for all Bond Broad Type \\
assets holdings.
\end{tabular}




\section{Appendix D: Morningstar Categories}

This table describes the fraction of fund observations in each Morningstar Category that are misclassified according to our baseline classification system between Q1 2017 to Q2 2018.

\begin{tabular}{|l|c|}
\hline \multicolumn{1}{|c|}{ Morningstar Category } & $\begin{array}{c}\text { Fraction of Bond-Fund Observations } \\
\text { Misclassified }\end{array}$ \\
\hline US Fund Ultrashort Bond & $41.89 \%$ \\
\hline US Fund Inflation-Protected Bond & $29.7 \%$ \\
\hline US Fund Short-Term Bond & $26.7 \%$ \\
\hline $\begin{array}{l}\text { US Fund Intermediate Core-Plus } \\
\text { Bond }\end{array}$ & $22.1 \%$ \\
\hline US Fund Intermediate Core Bond & $18.8 \%$ \\
\hline US Fund Corporate Bond & $8.90 \%$ \\
\hline
\end{tabular}




\author{
Appendix E: \\ Link to Morningstar's Response
}

Appendix F:

Link to Our Reply

Appendix G:

Link to Morningstar's Second Response Comments

Appendix H:

Link to Our Reply to these Comments 


\section{Appendix I: Replicating Morningstar Ratings and Understanding the Relationship between Misclassification and Morningstar Star Ratings}

We begin our analysis by replicating Morningstar's 3-year ratings for our collection of bond mutual funds. Morningstar's methodology is linked here, and utilizes a return with a "risk-adjustment" within Morningstar Categories (listed in Appendix D). We are able to explain $91.31 \%$ of the variation in the ratings of bond share-class/quarter observations in the last 2 years using ratings constructed from historic returns, a proxy risk-free rate, Morningstar's risk-aversion assumption, and historic Morningstar categories. ${ }^{9}$

Through this replication exercise, however, we find that the risk adjustments do very little to change the ranking of bond mutual funds within each category. Ranking funds by their raw 3-year excess returns and using the star-ranking percentile breakpoints gives almost the same exact ratings as ranking with a certainty equivalent excess return using Morningstar's risk aversion function (the former explains $90.70 \%$ of the variation as opposed to $91.31 \%$ of the variation explained by the latter method). This implies that returns resulting from holding riskier bonds are not substantially adjusted by Morningstar's rating process; therefore, our finding that misclassified funds have higher Morningstar Stars could follow from the fact that these funds tend to hold riskier assets than their style-box peers. To explore this in more depth, in Appendix Figure I1 below, we simply separate and plot funds and their received Morningstar stars by the risk level of:

1.) The assets they actually hold (Yellow Bars); and

2.) The assets that they claim to hold in their self-reported survey responses (Blue Bars).

\footnotetext{
${ }^{9}$ The variation explained by our replicated stars decreases as we go further back in time to roughly $77.65 \%$ for the sample between Q3 2010 to Q1 2020. We suspect that this is because many previous US taxable bond funds have switched out of their rank-determining US Taxable Bond categories (for instance to target date mixed asset classes, etc.), and thus out of our sample collected through Morningstar Direct. In addition, Morningstar tweaked their categorization by backfilling the Intermediate Core-Plus Grade category through the data, affecting our rankings within historic Morningstar Categories.
} 


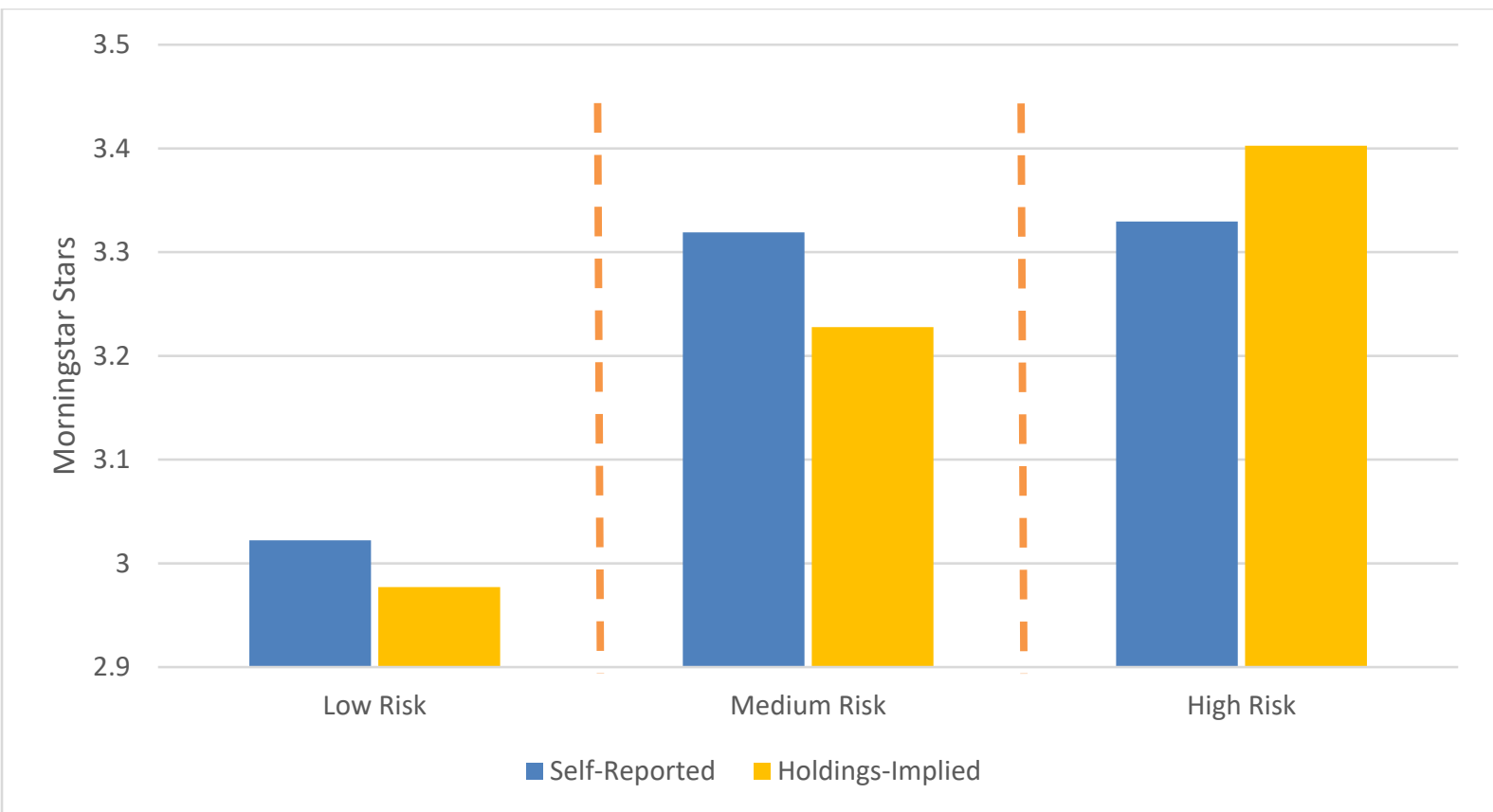

Appendix Figure I1. Morningstar Stars by Surveyed and Holdings Implied Credit Risk Group (Q3 2010 - Q2 2018)

From Appendix Figure I1, the Holdings-Implied risk categories (Yellow Bars) reflect the monotonic nature of the ratings to risky holdings. Higher risk funds tend to be assigned more stars than medium risk funds, which in turn have more stars than low risk funds.

This pattern is significantly more muted for the Self-Reported (survey-response) risk-style box implied risk levels (Blue Bars): bond funds in the medium risk category have almost the identical star average as that of the funds in the high risk category.

Given Morningstar's Star Rating methodology and formula, a fund thus needs to actually hold more risky assets to be ascribed more stars. This is further demonstrated in Appendix Table I1 where we run a horserace by regressing fund portfolios' Morningstar star ratings against Self-Reported and Holdings-Implied category indicators. Again, Star Ratings are monotonically increasing in the "True" Holdings-Implied categories, while exhibiting no relationship to the self-reported style-box categories after controls. These results collectively show that bond mutual funds can gain substantially more Morningstar stars (given the Star rating formula) by holding riskier assets. 
Appendix Table I1

\begin{tabular}{|c|c|c|c|}
\hline & $\begin{array}{c}(1) \\
\text { Morningstar } \\
\text { Rating }_{t}\end{array}$ & $\begin{array}{c}(2) \\
\text { Morningstar } \\
\text { Rating }_{\mathrm{t}}\end{array}$ & $\begin{array}{c}(3) \\
\text { Morningstar } \\
\text { Rating }_{\mathrm{t}}\end{array}$ \\
\hline Holdings-Implied Low Risk $\mathrm{t}_{\mathrm{t}-1}$ & - & - & - \\
\hline Holdings-Implied Medium Risk ${ }_{\mathrm{t}-1}$ & $\begin{array}{c}0.147 \\
(0.973)\end{array}$ & $\begin{array}{c}0.199 \\
(1.323)\end{array}$ & $\begin{array}{c}0.204 \\
(1.356)\end{array}$ \\
\hline Holdings-Implied High Risk ${ }_{t-1}$ & $\begin{array}{c}0.532^{* * *} \\
(3.111)\end{array}$ & $\begin{array}{c}0.527^{* * *} \\
(3.104)\end{array}$ & $\begin{array}{c}0.535^{* * *} \\
(3.148)\end{array}$ \\
\hline Self-Reported Low Risk $\mathrm{t}_{-1}$ & - & - & - \\
\hline Self-Reported Medium Risk ${ }_{t-1}$ & $\begin{array}{c}0.145 \\
(1.370)\end{array}$ & $\begin{array}{l}0.0425 \\
(0.393)\end{array}$ & $\begin{array}{l}0.0425 \\
(0.391)\end{array}$ \\
\hline Self-Reported High Risk ${ }_{t-1}$ & $\begin{array}{l}-0.0570 \\
(-0.392)\end{array}$ & $\begin{array}{l}-0.0403 \\
(-0.283)\end{array}$ & $\begin{array}{l}-0.0494 \\
(-0.346)\end{array}$ \\
\hline Reported Credit Score ${ }_{t-1}$ & $\begin{array}{c}-0.00193 \\
(-0.577)\end{array}$ & $\begin{array}{c}0.0322^{* * *} \\
(5.897)\end{array}$ & $\begin{array}{c}0.0322^{* * *} \\
(5.930)\end{array}$ \\
\hline Reported Duration $_{\mathrm{t}-1}$ & $\begin{array}{c}0.0518^{* * *} \\
(3.543)\end{array}$ & $\begin{array}{c}0.127^{* * *} \\
(4.483)\end{array}$ & $\begin{array}{c}0.126^{* * *} \\
(3.238)\end{array}$ \\
\hline Time FE & Yes & No & No \\
\hline Time x Morningstar Category FE & No & Yes & Yes \\
\hline Time x Duration Classification FE & No & No & Yes \\
\hline Observations & 11,330 & 11,294 & 11,281 \\
\hline Adjusted R-squared & 0.039 & 0.131 & 0.128 \\
\hline
\end{tabular}

This leads to the natural question, if stars can be gained by holding riskier assets, why do funds misclassify at all to give the appearance of being less risky with regard to their risk style boxes? In Appendix Table I2, we show evidence of one motivation. In particular, in Appendix Table I2, we find that for the same level of Morningstar ratings, investors have a preference for lower risk (and against indications of a high risk). We regress measures of mutual fund flows against a dummy variable indicating whether a fund is assigned a non-investment "High Risk" classification. We see that investors invest substantially less in these funds relative to other funds of the same Morningstar Rating. This is true throughout our sample. Additionally, investor flows seem only to correspond to the selfreported risk measure. The holdings-implied high risk indicator included in columns 2 and 4 has no power in explaining the direction or the magnitude of investor flows; that is if a 
fund is truly holding riskier assets, and yet through misclassification by its survey responses has achieved a low risk classification by Morningstar, then it effectively gained Morningstar Stars without suffering the adverse investor flow related consequences of being labeled a risky portfolio.

Appendix Table I2

\begin{tabular}{|c|c|c|c|c|}
\hline & (1) & (2) & (3) & (4) \\
\hline & Flow $_{t}>0$ & Flow $_{t}>0$ & Flow $_{\mathrm{t}}>0$ & Flow $_{\mathrm{t}}>0$ \\
\hline Self-Reported High Riskt 1 & $\begin{array}{c}-0.0513^{* *} \\
(-2.524)\end{array}$ & $\begin{array}{c}-0.0739 * * * \\
(-3.823)\end{array}$ & $\begin{array}{c}-0.0369^{* *} \\
(-2.101)\end{array}$ & $\begin{array}{c}-0.0545^{* * *} \\
(-3.081)\end{array}$ \\
\hline Holdings-Implied High Risk $\mathrm{t}_{-1}$ & & $\begin{array}{l}-0.0109 \\
(-0.872)\end{array}$ & & $\begin{array}{l}-0.0135 \\
(-1.102)\end{array}$ \\
\hline Reported Duration $_{t-1}$ & & $\begin{array}{c}-0.00693 \\
(-1.478)\end{array}$ & & $\begin{array}{c}0.00345 \\
(0.872)\end{array}$ \\
\hline 3 Year Return ${ }_{t-1}$ & & $\begin{array}{l}0.321^{*} \\
(1.726)\end{array}$ & & $\begin{array}{c}0.713^{* * *} \\
(3.254)\end{array}$ \\
\hline $\begin{array}{l}\text { Time X Morningstar } \\
\text { Rating FE } \\
\text { Time X Morningstar } \\
\text { Rating X Morningstar } \\
\text { Category FE }\end{array}$ & Yes & Yes & Yes & Yes \\
\hline $\begin{array}{l}\text { Observations } \\
\text { Adjusted R-squared }\end{array}$ & $\begin{array}{c}13,095 \\
0.076\end{array}$ & $\begin{array}{c}12,330 \\
0.082\end{array}$ & $\begin{array}{c}12,925 \\
0.109\end{array}$ & $\begin{array}{c}12,180 \\
0.119\end{array}$ \\
\hline
\end{tabular}

In summary, misclassification is related to higher Morningstar stars because misclassified funds have substantially riskier underlying holdings (as shown in Appendix Figure I1 and Appendix Table I1), which mechanically drives the rankings given the star rating methodology). Moreover, these same funds understate their underlying risk, as this lower risk perception attracts substantially higher investor flows conditional on Morningstar star ratings. 


\section{Appendix J: Fund Expenses and Fund Age}

In this table, we further analyze whether misclassified funds are more expensive than usual. We regress average expense ratio on the misclassified indicator whiling controlling for characteristics including the Fund Age. The average expense ratio is calculated at the fund level as the value weighted average of their respective share-class level values. Column (1) generates a "true" risk style fixed effect using holding related credit qualities, while column (2) uses a fund's reported risk style FE. The sample period is Q3 2010 to Q2 2018. t-statistics are double-clustered by time and fund.

\begin{tabular}{|c|c|c|}
\hline & $\begin{array}{c}(1) \\
\text { Average Expenses } \\
\text { A Ex }\end{array}$ & $\begin{array}{c}(2) \\
\text { Average Expenses } \\
\end{array}$ \\
\hline Misclassified $_{\mathrm{t}-1}$ & $\begin{array}{c}0.0829^{* *} \\
(2.228)\end{array}$ & $\begin{array}{c}0.148^{* * *} \\
(4.018)\end{array}$ \\
\hline Reported Credit Score $_{t-1}$ & $\begin{array}{l}0.00978^{* * *} \\
\quad(3.777)\end{array}$ & $\begin{array}{l}0.0205^{* * *} \\
(3.541)\end{array}$ \\
\hline Reported Duration $_{\mathrm{t}-1}$ & $\begin{array}{c}-0.00480 \\
(-0.427)\end{array}$ & $\begin{array}{c}-0.00767 \\
(-0.655)\end{array}$ \\
\hline Fund Age $_{t}$ & $\begin{array}{c}0.00796^{* * *} \\
(5.676)\end{array}$ & $\begin{array}{c}0.00796^{* * *} \\
(4.643)\end{array}$ \\
\hline Fund $_{\text {Age }_{t}}{ }^{*}$ Misclassified $_{t-1}$ & $\begin{array}{c}-0.00364^{*} \\
(-2.005)\end{array}$ & $\begin{array}{c}-0.00432^{* *} \\
(-2.134)\end{array}$ \\
\hline $\begin{array}{l}\text { Time x Morningstar } \\
\text { Reported Risk Style FE }\end{array}$ & No & Yes \\
\hline $\begin{array}{l}\text { Time x Morningstar True } \\
\text { Risk Style FE }\end{array}$ & Yes & No \\
\hline $\begin{array}{l}\text { Time x Morningstar } \\
\text { Category FE }\end{array}$ & Yes & Yes \\
\hline $\begin{array}{l}\text { Observations } \\
\text { Adjusted R-squared }\end{array}$ & $\begin{array}{l}9,335 \\
0.295\end{array}$ & $\begin{array}{l}7,573 \\
0.199\end{array}$ \\
\hline
\end{tabular}




\section{Appendix K: Fund Advisor and Distribution Fees}

In this table, we analyze whether misclassified funds are more expensive than usual with respect to advisor and distribution fees. In Panel A (B) we regress the average Advisor Fee (Distribution Fee) on misclassified dummy and control variables. The average fee variables are calculated at the fund level as the value weighted average of their respective share-class level values. The sample period is Q3 2010 to Q2 2018. t-statistics are doubleclustered by time and fund.

Panel A: Advisor Fees

\begin{tabular}{|c|c|c|c|}
\hline & $\begin{array}{c}(1) \\
\text { Advisor Fee }\end{array}$ & $\begin{array}{c}(2) \\
\text { Advisor Fee } \\
\end{array}$ & $\begin{array}{c}(3) \\
\text { Advisor Fee }\end{array}$ \\
\hline $\begin{array}{l}\text { Misclassified }_{\mathrm{t}-1} \\
{\text { Reported Credit } \text { Score }_{\mathrm{t}-1}} \\
\text { Reported Duration }_{\mathrm{t}-1}\end{array}$ & $\begin{array}{l}0.0382^{* * *} \\
(3.453)\end{array}$ & $\begin{array}{c}0.0245^{*} \\
(1.929) \\
0.00892^{* *} \\
(2.712)\end{array}$ & $\begin{array}{c}0.0242^{*} \\
(1.897) \\
0.00869^{* *} \\
(2.713) \\
-0.00508 \\
(-0.896)\end{array}$ \\
\hline $\begin{array}{l}\text { Time x Morningstar } \\
\text { Reported Risk Style FE } \\
\text { Time x Morningstar } \\
\text { Category FE }\end{array}$ & $\begin{array}{l}\text { Yes } \\
\text { Yes }\end{array}$ & $\begin{array}{l}\text { Yes } \\
\text { Yes }\end{array}$ & $\begin{array}{l}\text { Yes } \\
\text { Yes }\end{array}$ \\
\hline $\begin{array}{l}\text { Observations } \\
\text { Adjusted R-squared }\end{array}$ & $\begin{array}{l}4,935 \\
0.114\end{array}$ & $\begin{array}{l}4,437 \\
0.128\end{array}$ & $\begin{array}{l}4,437 \\
0.129 \\
\end{array}$ \\
\hline \multicolumn{4}{|c|}{ Panel B: Distribution Fees } \\
\hline & $\begin{array}{c}(1) \\
\text { Distribution Fee }\end{array}$ & $\begin{array}{c}(2) \\
\text { Distribution Fee }\end{array}$ & $\begin{array}{c}(3) \\
\text { Distribution Fee }\end{array}$ \\
\hline $\begin{array}{l}\text { Misclassified }_{\mathrm{t}-1} \\
\text { Reported Credit Score }_{\mathrm{t}-1} \\
\text { Reported Duration }_{\mathrm{t}-1}\end{array}$ & $\begin{array}{c}0.0546^{* * *} \\
(2.955)\end{array}$ & $\begin{array}{c}0.0337 \\
(1.723) \\
0.0103^{* *} \\
(2.390)\end{array}$ & $\begin{array}{c}0.0338 \\
(1.719) \\
0.00969^{* *} \\
(2.328) \\
-0.0183 \\
(-1.396)\end{array}$ \\
\hline $\begin{array}{l}\text { Time x Morningstar } \\
\text { Reported Risk Style FE } \\
\text { Time x Morningstar } \\
\text { Category FE }\end{array}$ & $\begin{array}{l}\text { Yes } \\
\text { Yes }\end{array}$ & Yes & $\begin{array}{l}\text { Yes } \\
\text { Yes }\end{array}$ \\
\hline $\begin{array}{l}\text { Observations } \\
\text { Adjusted R-squared }\end{array}$ & $\begin{array}{l}3,440 \\
0.030\end{array}$ & $\begin{array}{l}3,138 \\
0.040\end{array}$ & $\begin{array}{l}3,138 \\
0.047\end{array}$ \\
\hline
\end{tabular}

